\title{
A dimensão teológico-cristã da pessoa humana
}

\author{
The theological-Christian dimension of the human person
}

Renato Alves de Oliveira*

\begin{abstract}
Resumo
O objetivo deste artigo é demonstrar que a pessoa humana é uma grandeza ontológica que tem um fundamento divino. O ser da pessoa está edificado no ser de Deus. A origem do conceito de "pessoa" deu-se em solo teológico-cristão, no contexto das discussões cristológico-trinitárias no século IV. No ocidente, sua trajetória histórica tem um viés filosófico-teológico, oscilando entre um substancialismo sem relação até um relacionalismo sem substancialidade. A dimensão teológica da pessoa está em sua condição de imagem de Deus e de criatura chamada à existência por Deus, segundo a tradição judaica e cristã. Como criatura que recebe a sua existência como um dom, a pessoa está orientada para Deus. Entre Deus e a pessoa há uma relação interpessoal, um tu-a-tu. Em virtude de seu fundamento transcendente, a pessoa tem um primado onto-axiológico sobre as demais criaturas. A pessoa é detentora de um valor absoluto e não pode ser instrumentalizada em função do estado, do mercado e nem da religião. Esta pessoa é uma magnitude indefinível e mistérica, assim como o é o Deus que a criou. A pessoa é um reflexo do mistério de Deus. Todo amor, respeito e veneração prestados a Deus, também devem ser devotados à sua imagem, a pessoa humana.
\end{abstract}

Palavras-chave: Deus, pessoa humana, mistério, valor, dignidade, respeito e liberdade.

\begin{abstract}
The objective of this article is to demonstrate that the human person is an ontological greatness that has a divine foundation. The essence of the person is built in the being of God. The concept of the origin of person took place in theological-Christian ground, in the context of the Christological and Trinitarian discussions in the fourth century. In the West, its historical trajectory has a philosophical-theological bias, wavering between substantialism unrelated to rationalism without substantiality. The theological dimension of the person is in its image condition of God and creature called into existence by God, according to Jewish and Christian tradition. Like creature receiving his existence as a gift, the person is oriented toward God. Between God and the person there is an interpersonal relationship, one "tu-a-tu". Because of their transcendent foundation, the person has an onto-axiological primacy over other creatures. The person holds an absolute value and cannot be manipulated by the state, the market and nor religion. This person is an indefinable and a mystery magnitude, just as God its Creator. The person is a reflection of the mystery of God. All love, respect and veneration rendered to God must also be devoted to his image, the human person.
\end{abstract}

Keywords: God, human person, mystery, value, dignity, respect, freedom

Artigo recebido em 13 de fevereiro de 2016 e aprovado em 08 de junho de 2016.

* Doutor em teologia (2011), com especialização em dogmática, pela Pontifícia Universidade Gregoriana de Roma, Itália. Professor Adjunto do Departamento de Teologia da PUC Minas, de antropologia teológica e escatologia. País de Origem: Brasil. E-mail: praobh@yahoo.com.br

Horizonte, Belo Horizonte, v. 14, n. 42, p. 557-605, abr./jun. 2016 - ISSN 2175-5841 


\section{Introdução}

O ser humano, em sua composição ontológica, é constituído de corpo e de alma, sendo uma unidade dual e uma dualidade una de ambas dimensões. Ele é uma magnitude psicofísica e corpóreo-anímica. Uma investigação sobre a composição ontológica responde à questão a respeito do que é constituído o ser humano. Esta magnitude ontológica não é algo, mas alguém, uma pessoa humana. A reflexão sobre a pessoa humana medita sobre quem é este sujeito constituído por uma unidade de corpo e de alma. "À pergunta que interroga 'quem' é o homem não se responde com múltiplas e parciais respostas, como acontece no problema 'que' é o homem, mas com uma única palavra enquadrada no 'ser pessoal' do homem" (SCHÜTZ; SARACH, 1973, p. 73). O ser humano não se reduz à sua natureza, à sua materialidade espaço-temporal e nem a uma função, mas é uma pessoa. Por sua condição pessoal, o ser humano transcende a sua dimensão natural e material. Qualquer tentativa de reduzir a pessoa a um nível subumano viola a sua dignidade e o seu valor. A dignidade humana é um patrimônio sagrado e inviolável, pois a pessoa é a imagem divina na terra, segundo a tradição judaico-cristã. Deus é a magnitude fundante do ser pessoal, livre e social do ser humano. A pessoa humana é uma grandeza indefinível e mistérica, assim como Deus o é. A pessoa é um reflexo do mistério de Deus. Assim, o mesmo respeito e a mesma veneração que se tem por Deus deve-se ter pela pessoa, sua imagem-representação.

\section{Uma breve história filosófico-teológica do conceito de pessoa}

A compreensão do ser pessoal do ser humano é um dado fundamental para a antropologia cristã. A pergunta sobre quem é o ser humano precede toda questão a seu respeito. "Não deve, porventura, toda a pergunta sobre a pessoa do homem preceder e exceder em importância todas as demais questões sobre o homem?" (SCHÜTZ; SARACH, 1973, p. 73). Não é possível compreender o ser humano, passando à margem de seu ser pessoal. Nascido no contexto patrístico, o conceito 
de pessoa, em sua evolução histórica, oscilará entre dois pólos: substancialismo desrelacionado e relação dessubstancializada.

\subsection{A origem do conceito de pessoa}

Como e onde surgiu o conceito de pessoa? Inicialmente, seria possível conjecturar que teria nascido em um contexto antropológico e, posteriormente, teria migrado para o contexto teológico. Em outros termos, a experiência que o ser humano faz de si mesmo seria determinante para a representação e conceituação do ser divino. É como se o ser humano fizesse primeiramente uma experiência de si mesmo, enquanto um ser pessoal, e depois, a partir dela, interpretasse a divindade transcendente. Assim, o que fundaria a condição do ser pessoal do divino seria a condição de ser pessoal do ser humano. No entanto, o teólogo luterano W. Pannenberg (1928-2014) elenca algumas razões para se duvidar da exatidão histórico-especulativa desta tese. O luterano argumenta que é a partir do conhecimento e da relação com Deus que o ser humano se autocompreende e se autopercebe. É a relação com Deus que fundaria o ser pessoal do ser humano. Assim, "a origem do conceito de pessoa se encontra no terreno da experiência religiosa, no encontro com a realidade divina" (PANNENBERG, 1974, p. 20). Encontrando-se com Deus, o ser humano se encontraria consigo mesmo. Deste modo, o conceito de pessoa não teria sua origem na antropologia, mas na teologia.

A antropologia bíblica não conheceu propriamente o conceito de pessoa, mas seu conteúdo relacional. Ela teve acesso àquilo que o conceito expressa. Na visão bíblica, o ser humano, como imago Dei, seria concebido mediante a sua relação com Deus (inferioridade e dependência), com o mundo (superioridade) e com o outro (igualdade). A relação do ser humano com Deus (dimensão teologal) seria o fundamento da percepção de sua dimensão transcendente em relação ao mundo e de igualdade em relação ao outro, ao semelhante (RUIZ DE LA PEÑA, 1998, p. 154-155; SIERRA, 2002, p. 109). Esta tríplice referência mostraria que o ser humano é um ser essencialmente relacional. É inerente à ideia de pessoa um 
conteúdo relacional. A pessoa é um nó de relações. A relacionalidade é uma dimensão constitutiva da pessoa. Deste modo, o conteúdo relacional com que o ser humano é apresentado, no horizonte bíblico, estaria em sintonia com o significado do conceito moderno de pessoa humana.

O conceito de pessoa surgiu em um contexto teológico-cristão. A tese de que o pensamento grego não conheceu o conceito de pessoa é compartilhada por filósofos como X. Zubiri (1984, p. 323), J. Marías (1971, p. 33-34), E. Mounier (1964, p. 23) e teólogos como O. Clément (1972, p. 32-35), J.L. Ruiz de la Peña (1988, p. 155) e outros (SCHÜTZ; SARACH, 1973, p. 74; RUBIO, 2001. p. 304; SAYÉS, 2002, p. 217; SCOLA; MARENGO; PRADES LÓPEZ, 2000, p. 185; PESSOA, 2001, p. 2262). A filosofia grega, particularmente a platônica, não teria conhecido uma concepção pessoal do ser humano porque o concebia como um espírito, uma realidade pertencente ao mundo do eterno, do imutável e do universal. O espírito divino seria transcendente em relação à realidade sensível, particular e múltipla. As características universais do espírito se particularizariam no corpo, a parcela da realidade da matéria. Esta individualização faria com que o ser humano se tornasse uma abreviatura do mundo sensível. A individualização corporal da universalidade do espírito, resultando o ser humano, seria um sinal de decadência para o espírito. A fase encarnada do espírito seria provisória e purificatória. Desta forma, o espírito almejaria, pelo advento da morte, se libertar das ataduras e do confinamento corporal e retornar ao seu estado eterno, universal e imortal. O espírito, em sua dimensão desencarnada, teria um alto grau de pureza (MÜLLER; HALDER, 1974, p. 445; RUBIO, 2001, p. 304; RUIZ DE LA PEÑA, 1988, 156; SCHÜTZ; SARACH, 1973, 74).

A ausência do conceito de pessoa fez com que a antropologia grega utilizasse outras categorias como essência (ousía), substância (hypóstasis) e natureza (phýsis). O termo prósopon ("o olhar dirigido a"), em um primeiro momento, designava a máscara que cobria o rosto do ator que desempenhava um papel no teatro clássico, principalmente na tragédia. A máscara caracterizava o personagem 
teatral. A pessoa era o personagem. Portanto, o termo prósopon se referia à face ou ao rosto, a parte exterior e visível. Os estóicos concebiam os seres humanos como pessoas ou personagens que atuavam no teatro do mundo. A pessoa significava o papel ou a função que o ser humano representava no teatro. Do termo prósopon teria originado a palavra latina persona, que vem de personare (ressoar, soar através de), no sentido de uma amplificação da voz dos atores do teatro. Tratava-se de fazer ressoar a voz do ator mascarado, através de um orifício ou cavidade. O vocábulo "pessoa", também, era usado, na antiguidade pelos romanos, no sentido jurídico, como sujeito legal. O termo "pessoa" tinha um significado de pessoa jurídica ou de sujeito detentor de direitos e deveres. Um mesmo homem poderia ter diferentes personae, ou seja, diversos papéis sociais ou jurídicos (LORDA, 2009, p. 179; PESSOA, 2001, p. 2262).

O conceito de pessoa, na teologia, passou por uma transformação, em termos de conteúdo. A origem do conceito não foi marcada por um desejo filosófico de autocompreensão do ser humano, mas se deu no cenário de uma correta interpretação da imagem cristã de Deus e da figura de Jesus Cristo, ou seja, no contexto dos debates trinitários e cristológicos, no período patrístico (LADARIA, 1998, p. 72; LORDA, 2009, 177; SCHÜTZ; SARACH, 1973, p. 75; RATZINGER, 2005, p. 135; VILLA, 2000, p. 594; MCPARTLAN, 2004, p. 1393). Era mister distinguir o significado de natureza e de pessoa, que por sua vez não se tratava de uma questão puramente terminológica, mas também metafísica. A fé cristã professava que Deus era constituído por uma unidade essencial e uma trindade de pessoas distintas (Pai, Filho e Espírito Santo). As três pessoas divinas não seriam constituídas de três papéis, aspectos ou funções exercidas por um Deus que é uno e único, como pensavam os adeptos do modalismo e do sabelianismo, mas seriam três pessoas distintas. Aqui, o conceito de pessoa aplicado às pessoas divinas da trindade não remeteria à ideia originária do termo grego prósopon (papéis exercidos pelos atores teatrais) e nem pelo termo latino persona (dimensão jurídica), mas se tratava de relações. O Deus cristão não seria uma realidade singular absoluta e não-relacional, mas uma unidade trina. 
Se o absoluto é pessoa, não se trata de um singular absoluto. Nesse sentido, o conceito de pessoa inclui necessariamente a superação do singular. Mas, ao mesmo tempo, devemos reconhecer que a profissão de fé num Deus que é pessoa na forma de três pessoas rompe com todo e qualquer conceito ingênuo e antropomorfo de pessoa. De uma maneira velada se afirma que a personalidade de Deus ultrapassa infinitamente a maneira de ser pessoa do ser humano (RATZINGER, 2005, p. 134).

Tertuliano (160-220), membro da escola de Antioquia, foi o teólogo latino que criou o vocabulário trinitário, aplicando o conceito de pessoa às três pessoas divinas distintas: Deus seria constituído por uma única substância e três pessoas (LADARIA, 2005, p. 156-164). Em Deus, haveria substância (essência) e relação. Os padres capadócios (Basílio de Cesaréia, Gregório de Nissa e Gregório de Nazianzeno) operaram uma equiparação entre os termos prósopon e hypóstasis (substância). Esta equiparação promoveu uma clarificação no conceito trinitário de pessoa: Deus seria constituído por uma natureza e três sujeitos. A natureza divina comum constituía a unidade das três pessoas divinas. Santo Agostinho (354-430) (1995, 202-203), em sintonia com os padres gregos, defendia uma equivalência entre os termos hipóstase e pessoa: o que para os gregos é a hipóstase, para os latinos é a pessoa. Assim, o bispo de Hipona reafirmou a tese, de que em Deus, haveria "uma essência e três pessoas".

Deus é um em sua constituição substancial e trino na constituição das pessoas divinas. A unidade divina realiza-se em três pessoas divinas. A unidade substancial está presente, igualmente, nas três pessoas divinas. O que especifica e distingue as pessoas na trindade não é a natureza divina, que é a mesma nas três pessoas divinas, mas a relação. Deus se relaciona e se comunica, interiormente, consigo mesmo. Em Deus há um eu e um tu, ou seja, um "nós". Deus não é uma solidão eterna e nem um ser hermético, mas é diálogo, relação, alteridade e comunicação de vida. É um absoluto relacional e um sujeito dialógico. Não são três deuses, mas três pessoas divinas distintas, cada uma com sua especificidade e abertas à comunhão. Deus se realiza se autocomunicando consigo mesmo (trindade imanente) e para fora de si mesmo (trindade econômica). A compreensão segundo a qual o Deus cristão é um em sua substância, mas constituído no seu interno pela 
relação, pela diferenciação e pelo diálogo, demonstra a necessidade do uso do conceito de pessoa, não no sentido original de prósopon (papel, função, rosto) e nem de persona (noção jurídica).

Deus é Pai, não em relação a si mesmo, mas em relação ao Filho. Deus é Pai na relação com o outro, que é o seu Filho. Em Deus, a categoria "Pai" é um conceito relacional. "A primeira pessoa não gera o Filho como se o ato de gerar se acrescentasse à pessoa pronta; na verdade ela é o ato de gerar e de entregar-se. Ela é idêntica ao ato de entrega. Ela só é pessoa como esse ato" (RATZINGER, 2005, p. 137). A encarnação significa que o Filho, gerado eternamente no "útero" do Pai, torna-se o Filho temporalizado. O Pai se autocomunica, externamente, na encarnação do Filho. Jesus Cristo, o Filho encarnado e temporalizado, é uma só pessoa, constituída por uma dualidade de naturezas: divina e humana. Ele é consubstancial a Deus, pela sua divindade, e consubstancial a nós, pela sua humanidade, como afirmou o Concílio de Calcedônia (451). O Espírito Santo procede da auto-oferta mútua da comunhão relacional entre o Pai e o Filho. A autocomunicação de Deus para o fora dele mesmo, ou seja, para o diferente daquilo que ele é não significa uma descaracterização ou um rebaixamento na sua divindade. Com outras palavras, o fato de o Deus cristão ser constituído por uma unidade de essência e uma trindade de pessoas não significa que ele é um deus de segunda classe, comparando-se com o monoteísmo judaico e muçulmano, mas significa que Ele é diverso, plural e dialogal, no seu interior. O Deus cristão se autocomunica com o ontologicamente diverso daquilo que é e continua sendo o mesmo. Cada pessoa divina é, essencialmente, plena em si mesma. Deus se possui, doando-se e se doa, possuindo-se. No caso do cristianismo, dizer Deus é evocar uma dimensão pessoal e relacional. "Pessoa em Deus significa relação. A relação não é algo que se acrescenta à pessoa, mas é a pessoa mesma; a pessoa, segundo a sua essência, aqui existe só como relação" (RATZINGER, 2007, p. 182). A relação não é um acidente, como pensava Aristóteles, mas uma das formas primigênias do real, que constitui a realidade suprema das pessoas divinas. É incorreto pensar que 
primeiro se tem a pessoa e depois vem a relação. A pessoa não é anterior à relação. A pessoa é um sinônimo de relação. As duas realidades são simultâneas.

O fato do Deus cristão se autocomunicar com ele mesmo constitui o fundamento da condição de possibilidade dele se autocomunicar exteriormente com o diverso dele mesmo. É se autocomunicando para fora de si mesmo, que Deus pode criar um ser à sua imagem e semelhança. O Deus cristão ao criar uma criatura, à sua imagem, já o cria dotado de uma capacidade relacional. Em relação ao conceito de pessoa, há uma passagem da dimensão teológica para a antropológica. Somente um Deus pessoal é capaz de criar uma relação, uma pessoa, um tu, com quem pode dialogar. O ser humano como imagem de Deus é dotado de uma capacidade pessoal, relacional e dialogal. Contudo, o ser humano é pessoa humana e as pessoas, que constituem a trindade, são pessoas divinas. Não se pode colocar no mesmo plano, em termos de conteúdo, a dimensão pessoal das pessoas divinas, na trindade, e da pessoa humana, pois entre ambas visões há uma dessemelhança ontológica. As pessoas divinas são subsistentes, existem por si mesmas, enquanto o ser humano, como criatura, recebe a sua existência como um dom de um Outro.

A patrística quando deseja se referir à dimensão humana e relacional do sujeito usa a categoria "imagem de Deus". Quando a patrística refere-se à dignidade e ao valor do ser humano está expressando o conteúdo que denota o conceito de pessoa. Toda pessoa é dotada de um caráter ontológico e axiológico. Será necessário esperar a teologia medieval para assistir a uma elaboração técnica do conceito de pessoa humana, isto é, o desdobramento do conceito no campo antropológico. A teologia medieval enfatizará o caráter substancial do conceito de pessoa. 


\subsection{A teologia medieval}

A primeira definição cunhada, sobre a pessoa humana, foi elaborada por Boécio (480-524) (cap. III) que, influenciado pela filosofia aristotélica, declarou-a: "substância individual de natureza racional" (naturae rationalis individua substantia). O caráter substancial se referiria àquilo que existe em si, por si e não em outro. Eu sou eu e não o outro. A pessoa seria caracterizada pela independência. A individualidade denotaria a singularidade, a especificidade, a irrepetibilidade e o caráter intransferível: a pessoa seria incomunicável e inconfundível, com qualquer outra realidade. A natureza racional destacaria que apenas a pessoa humana seria dotada de capacidade intelectiva, sendo capaz de assimilar todas as coisas. A racionalidade, também, seria um elemento que distinguiria a pessoa humana dos demais seres irracionais.

A definição de Boécio está carregada de um teor formal, ontológico e científico. Trata-se de uma visão estática que ignora o caráter relacional e corpóreo da pessoa. A ênfase encontra-se na racionalidade e na individualidade como elementos distintivos da pessoa humana em relação às demais criaturas. A dimensão relacional, um elemento constitutivo das pessoas divinas, está ausente na definição boeciana, que se aplica somente à pessoa humana. O conceito de pessoa elaborado por Boécio pode ser aplicado somente à pessoa humana e não às pessoas divinas (LORDA, 2009, 180; ROVIRA BELLOSO, 1998, p. 700-701).

A definição de Boécio exercerá uma grande influência no período medieval de modo que os autores se posicionarão aceitando, refutando ou corrigindo a elaboração boeciana. Ricardo de São Vitor (1110-1173) reagiu à definição de Boécio, corrigindo-a visto que o seu conceito contemplava somente a pessoa humana. Ricardo faz uma distinção entre sistir (refere-se à natureza) e ex-sistir (vir de, originar-se de). A pessoa seria caracterizada pelo sistir, ou seja, pela natureza. Esta percepção não consistiria numa negação da independência e nem da subsistência da pessoa, pois a relação em questão seria concebida como uma relação subsistente 
(PESSOA, 2001, p. 2263). Ricardo (livro IV, cap. 22) define a pessoa divina como a "existência incomunicável própria da natureza divina" (divinae naturae incommunicabilis existentia). O próprio da pessoa não seria a individualidade, como afirmava Boécio, mas a existência. O caráter incomunicável da existência significaria o "modo de existir, pessoal intransferível, idêntico a si mesmo, distinto dos outros modos de existir" (ROVIRA BELLOSO, 1998, 701). O incomunicável seria aquilo que é próprio de cada pessoa. Ricardo substituiu a expressão "substância individual" da definição de Boécio pela incomunicabilidade e independência existenciais que constituem a pessoa. O desejo de Ricardo era elaborar um conceito de pessoa que pudesse ser aplicado não só à pessoa humana, como fez Boécio, mas também às pessoas divinas (SCHÜTZ; SARACH, 1973, p. 76).

Tomás de Aquino (1224-1274) acolhe a definição boeciana. O Angélico substitui o conceito de "substância" pelo de "subsistência", cujo significado é: "o que existe em si e não em outro" (TOMÁS DE AQUINO, 2001, I, q. 29, a. 2, resp.). Um ser subsistente é o que existe em si, por si e não em outra realidade. Segundo Tomás, (2001, I, q. 29, a. 3, resp.), "pessoa significa o que há de mais perfeito em toda a natureza, a saber, o que subsiste em uma natureza racional". Tudo o que é perfeito pode ser atribuído a Deus, o qual é o apogeu da perfeição. Neste sentido, se poderia atribuir a Deus o conceito de pessoa. No entanto, o conceito de pessoa aplicável a Deus não se refere ao termo prósopon (papel), mas, sim, no sentido que o termo passou a significar: "realidade subsistente" (TOMÁS DE AQUINO, 2001, I, q. 29, a. 3, ad 2-3). As pessoas divinas seriam concebidas como relações subsistentes. As pessoas divinas se "distinguem pelas relações" (TOMÁS DE AQUINO, 2001, I, q. 40, a. 2). O que constitui cada pessoa divina seria a sua relação com as outras. O conceito de relação aplicado a Deus "não é como um acidente que existe num sujeito; ela é a própria essência divina. Por conseguinte, é subsistente como a essência divina" (TOMÁS DE AQUINO, 2001, I, q. 29, a. 4, resp.). Para o filósofo Aristóteles, a relação era concebida como um acidente, e não como uma substância, à qual o sujeito estava submetido. Neste sentido, Tomás reformulou o conceito de relação, dando-lhe um significado diferente do 
aristotélico, para aplicá-lo a Deus. Assim, a relação significaria a própria essência constituinte de Deus. Em sua essência divina, Deus seria relação. A pessoa divina significaria a relação subsistente. O termo "pessoa" significaria relação e essência. As pessoas divinas seriam constituídas por relações subsistentes. "Se a relação está contida na significação de pessoa divina, e não na significação de pessoa angélica ou humana, não se segue que o termo pessoa seja atribuído de modo equívoco. Tampouco, de maneira unívoca, pois [...] nada se pode atribuir, de maneira unívoca, a Deus e as criaturas" (TOMÁS DE AQUINO, 2001, I, q. 29, a. 4, ad 4).

A definição de João Duns Escoto (1265-1308) (Lectura I, dist. II, pars II, q. 1-4) está mais próxima de Ricardo de São Vitor do que de Boécio: "a pessoa é a substância incomunicável de natureza racional". O acento se encontraria na incomunicabilidade da pessoa. O objetivo de Duns Escoto seria o de "salvaguardar a singularidade, irrepetibilidade, autonomia e independência ontológica" da pessoa individual (RUIZ DE LA PEÑA, 1988, p. 160). A comunicabilidade seria sinônimo de dependência: a nossa natureza se personaliza enquanto se lhe acrescenta a negação da comunicabilidade, isto é, da dependência (JOÃO DUNS ESCOTO, 1960).

As definições medievais sobre a pessoa focalizaram a subsistência, a incomunicabilidade, a independência, a unicidade e a irrepetibilidade, demonstrando uma primazia do substancial sobre o relacional. A estaticidade do substancialismo desrelacionado das definições medievais estava mais preocupada em mostrar a diferenciação ontológica entre o ser humano e as demais criaturas, o ser humano e as pessoas divinas, do que em definir propriamente o ser pessoal do homem. A ausência de um núcleo ôntico compacto na definição do ser pessoal do ser humano, transformou-o em um objeto passivo e não em um sujeito ativo das relações. A ausência da dimensão relacional, da autopossessão, da dinamicidade, da autopertença e da autodisposição (aquele que dispõe de si) pode transformar a pessoa num solipsismo e num ostracismo pessoais, de modo que o sujeito permanece enclausurado em sua própria suficiência. O ser humano é pessoa 
quando é capaz de dispor de si, ou seja, se tornar disponível.

É importante salientar, que não é somente a dimensão de ser-em-si da subsistência e da autopossessão, que especifica a pessoa. Não se pode esquecer, que o aspecto relacional é inerente à dimensão pessoal do sujeito. A carência do aspecto relacional, na definição do ser pessoal, desemboca numa visão solipsista do sujeito. Será a filosofia contemporânea que retomará a dimensão relacional da visão bíblica como componente constitutivo do ser humano.

\subsection{Da modernidade à contemporaneidade}

A guinada antropocêntrica da modernidade iniciou-se com o filósofo René Descartes (1596-1650), para quem o sujeito estaria encarcerado em uma egologia, isto é, relaciona-se, única e exclusivamente, consigo mesmo. A busca pelo fundamento do conhecimento levou Descartes a fazer da subjetividade, o essencial da pessoa. O eu cartesiano, o espírito, seria a expressão da autoconsciência pensante ensimesmada em sua operação ad intra. O solipsismo cartesiano não passa por uma consciência corporal. Seria um eu pensante ab-soluto e desconectado da corporeidade. Uma espécie de metafísica da subjetividade. Sendo assim, o eu pensante se apreenderia como distinto de seu corpo e, consequentemente, descolado de sua dimensão mundana, temporal e histórica. Seria uma consciência egóica que não se relacionaria com o mundo objetivo. $\mathrm{O}$ eu pensante seria uma realidade desrelacionada. Descartes definiu a natureza de sua existência como uma res cogitans, uma realidade pensante. A res cogitans (espírito, subjetividade), a coisa não-extensa, seria de uma natureza totalmente distinta da res extensa (realidade corpórea, material). A substância pensante seria o pensamento em ato e o pensamento em ato seria uma realidade pensante. A realidade pensante se apreenderia pensando e existindo, simultaneamente. Não haveria uma diferença entre ser e pensar (DESCARTES, 1999, p. 261-262). A pessoa não seria vista como uma magnitude ontológica, mas seria reduzida a uma 
realidade psicológica. Nesta visão psicologizada de Descartes, a pessoa significaria a consciência de si mesmo.

A definição proposta pelo filósofo empirista inglês J. Locke (1632-1704) (livro II, cap. 27) significou um avanço em relação à definição cartesiana: a pessoa é um "ser inteligente e pensante, dotado de razão e reflexão, consciente de sua identidade e de sua permanência no espaço e no tempo". Na visão de Locke, a pessoa teria consciência do mundo, no qual está inserida. Esta percepção não se verificou em Descartes. Seguindo a coordenada cartesiana, que reduziu o eu à consciência, um outro empirista inglês, D. Hume (1711-1776) (1999, p. 35), concebeu a consciência humana como um simples feixe ou coleção de percepções. Hume negaria o eu, negando, previamente, o conceito de substância.

A visão psicologizada da pessoa, presente em Descartes, encontrou receptividade no idealismo alemão. Para a metafísica do eu de J.G. Fichte (17621814), o eu do homem é uma divindade que canta eternamente que eu sou aquele sou (MOLTMANN, 1991, p. 135). A constituição da pessoa passaria pela identificação com o eu sem passar pela mediação do tu. A pessoa se define por si mesma, por seu eu. No idealismo alemão, havia uma tendência em confluir o ser absoluto com a consciência do eu. O absoluto tenderia a particularizar-se na autoconsciência do sujeito. Seguindo a linha da pessoa como autoconsciência, F. Hegel (1770-1831) (1981, p. 299) afirma que haveria uma coincidência entre o "próprio Espírito absoluto, sua liberdade absoluta, perfeita, a consciência desta infinitude em si e a personalidade livre, perfeita". O idealismo alemão sacrificou a singularidade e a concretude da existência em vista da objetividade do Espírito absoluto. O ser humano aconteceria quando a universalidade do espírito se particularizasse. Haveria um primado do universal sobre o particular. A subjetividade da pessoa concreta se dissolveria na abstração racional. Diante da visão racionalista e psicologizada da pessoa, o filósofo existencialista dinamarquês S. Kierkegaard (1813-1855) protestou chamando a atenção para a dimensão existencial, concreta, finita e contingente da pessoa. 
O marxismo clássico, de certo modo, se levantou como uma instância crítica diante da concepção abstrata e subjetivista do sujeito, preconizada pela filosofia racionalista e idealista. K. Marx (1818-1883) define o sujeito como um "conjunto de relações sociais" (MARX; ENGELS, 1986, p. 108). O sujeito seria um feixe de relações. Enfatiza-se o caráter social e coletivo do sujeito. No entanto, para o marxismo clássico, a subjetividade pessoal se dissolveria no anonimato coletivista da sociedade. O sujeito seria engolido pela coletividade. A dimensão pessoal do sujeito seria sacrificada em vista da coletividade. O universo das relações sociais se situaria na impessoalidade da espécie, da produção e do trabalho. Segundo M. Buber (1878-1965) (1986, p. 58), "Marx não acolheu em seu conceito de sociedade o elemento da relação real entre o eu e o tu, realmente diferentes, e por isso opôs a um individualismo alheio à realidade de um coletivismo não menos irreal". Assim como o sujeito se dissolve no abstracionismo do idealismo, ele, também, se dissipa no coletivismo marxista.

O resgate da condição pessoal do ser humano passa pela recuperação da relação interpessoal. A fenomenologia se apresenta com este intento, destacando no ser humano a sua condição de sujeito frente ao objeto e de eu frente ao tu (HUSSERL, 1993). O tu não poderia ser objetificado ou coisificado, pois comporia a constituição relacional do eu. O tu estaria orientado para o eu e vice-versa. As demais realidades, que estariam diante do eu, não nutririam uma relação interpessoal com ele. A fenomenologia husserliana implode o interior do solipsismo cartesiano, fazendo com que o ser humano se abra para a intersubjetividade, a interpessoalidade e para o mundo que o circunscreve.

O humanismo de M. Scheler (1874-1928) (1948, p. 15, V.1) deu um passo à frente em relação à perspectiva husserliana, demonstrando a dimensão axiológica da pessoa: "o valor da pessoa é superior a todo valor de coisas, organizações e comunidades". A pessoa teria um primado axiológico sobre os objetos, as estruturas e as instituições. Compreende-se, por pessoa, "a unidade de ser concreta e essencial", na qual se fundamentam "todos os atos essencialmente diversos" 
(SCHELER, 1948, p. 15, V. 2). A pessoa se encontraria totalmente presente, em cada ato realizado na sua relação com Deus, com o mundo, com o outro e consigo mesma. Scheler posicionou-se contrariamente a toda impessoalidade, coisificação e desvalorização da pessoa. A pessoa seria uma "forma de existência única, essencial e necessária do espírito concreto" (SCHELER, 1948, p. 180, V. 2) e portadora de uma dimensão moral, transcendental e relacional.

As intuições de Scheler foram desenvolvidas pelo personalismo dialógico, cujos principais representantes são F. Ebner (1882-1931) e M. Buber (1878-1965). O primeiro filósofo a tematizar sobre a fecundidade dialógica entre o eu e o tu foi L. Feuerbach (1804-1872). "O outro é o meu Tu, o meu outro Eu, o meu interior revelado. [...] Somente no outro tenho consciência da minha humanidade", "sinto que sou homem" (FEUERBACH, 1997, p. 199). O eu e tu formariam uma unidade, uma comunidade. Entre ambos, haveria uma "diferença qualitativa e crítica" (FEUERBACH, 1997, p. 199). A posição de Feuerbach significou uma recuperação do ser pessoal, que supõe uma relação eu-tu, excluindo uma visão autosuficiente e autoconsciente da pessoa, apoiada sobre si mesma como a defendida, por exemplo, por Descartes, Fichte e Hegel. A posição personalista de Feuerbach superou a visão psicologizada e individualista do sujeito. Esta posição foi precursora do surgimento do personalismo dialógico de Ebner e de Buber. Para Ebner, uma vida, autenticamente, humana se apoiaria na relação eu-tu. A vida seria dialogia, interatividade, reciprocidade e humanização. $\mathrm{O}$ eu e o tu se implicariam mutuamente: sem o tu não é possível que o eu aconteça (MOLTMANN, 1991, p. 134-135). A subjetividade seria intersubjetividade, o existente seria coexistente, a humanidade seria co-humanidade. A descoberta do tu provocou uma "revolução copernicana no pensamento moderno" (BUBER, 1986, p. 58). Seria diante do tu que o ser humano se descobriria como eu. $\mathrm{O}$ eu e o tu se revelariam reciprocamente. Um estaria orientado para o outro. "O eu se realiza na relação com o tu; é tornando eu que digo tu" (BUBER, 2001, p. 13). O encontro entre o eu e o tu conduz ao nós: "união de diversas pessoas independentes que alcançaram a 'mesmidade' e a responsabilidade própria" (BUBER, 1986, p. 104-105). O nós 
arranca o ser humano do anonimato e da impessoalidade. $O$ tu estaria, potencialmente, orientado para o nós. A vida humana seria um encontro dialógico entre duas existências pessoais que estariam em uma relação recíproca, realizandose e reconhecendo-se um no outro. O fundamento da interpersonalidade, compreendida como comunhão entre as pessoas, estaria na relação da pessoa com um Deus pessoal. Relacionando-se com o tu humano, o ser humano se perceberia aberto e relacionado com o tu divino: "Deus é o verdadeiro Tu do verdadeiro e permanente Eu do homem" (MOLTMANN, 1991, p. 140).

O pensamento buberiano tem um pano de fundo bíblico. A corrente personalista gozou da simpatia e da adesão de muitos pensadores cristãos como E. Brunner, R. Guardini, E. Mounier, J. Lacroix, M. Nédoncelle e outros. Analisando a filosofia do encontro dialógico, J.L. Ruiz de la Peña (1988, p. 164) verifica que a mesma necessita de um reajuste: "conceber o ser pessoal em chave exclusivamente relacional, apoiado no fio delgado do 'entre', pode desembocar em um puro atualismo". A observação de Ruiz de la Peña pode ser constatada verificando a conceituação de pessoa, segundo o teólogo protestante E. Brunner (1889-1966): o ser humano se tornaria um ser pessoal quando fosse capaz de responder a Deus de tal maneira que por esta resposta, Deus mesmo se glorifique e comunique (RUIZ DE LA PEÑA, 1988, p. 164). Ou seja, o constitutivo pessoal do ser humano se referiria à capacidade de escutar e de responder à palavra criadora de Deus. Correse o risco de que a pessoa humana seja reduzida à sucessão de atos pontuais de resposta. É necessário perceber que a pessoa é uma magnitude relativamente autônoma e goza de um caráter ôntico.

Constata-se que, passados muitos séculos, não há uma posição unânime diante do conceito de pessoa, que oscila pendularmente entre dois extremos: "substancialismo des-relacionado e relação dessubstancializada" (RUIZ DE LA PEÑA, 1988, p. 164-165). O primeiro está presente desde Boécio até Duns Escoto e o segundo está presente no personalismo dialógico. A pessoa é o ser que dispõe de si, o ser-em-si, a "suidade" (ZUBIRI, 1984, p. 49). O ser humano é constituído de 
uma infra-estrutura ôntica (corpo-alma) necessária para a compreensão do ser pessoal. A sua constituição psicoorgânica é a condição de possibilidade para se postular a sua subjetividade pessoal. No que tange ao ser humano, o quem (a pessoa) tem como pressuposto o que (psicofísico). Na composição ôntica do ser humano, já está presente uma aptidão para a relação: a intencionalidade e a receptividade, próprias do espírito; a socialibilidade, a mundanidade e a expressividade, próprias do corpo. A índole relacional não se dá numa pura subjetividade pensante e descorporalizada, mas supõe uma dimensão corpórea, numa subjetividade encarnada. O corpo é mediador da relação, do diálogo e do encontro.

O constituinte da pessoa é a relação, o ser-para. A finalidade de uma autopossessão subsistente é ser-para-a-relação. O que especifica e caracteriza o ser humano é o ser pessoal, a relação e não a natureza: "mantida com todo rigor a noção de pessoa como um sujeito distinto realmente de sua natureza, fica volatilizado o eu pessoal. Isto não pode ser. É o eu pessoal quem executa seus atos" (ZUBIRI, 1986, p. 108). "A pessoa se dispõe de si (subsiste) para tornar-se disponível (para relacionar-se) e só se torna disponível (relaciona-se) se dispõe de si (se subsiste)" (RUIZ DE LA PEÑA, 1988, p. 165-166). A pessoa é uma confluência entre subsistência e relação.

Observando o percurso histórico do conceito de pessoa, conclui-se que nem a subsistência e nem a relação são suficientes para a definição de tal conceito. Uma subsistência desprovida de relação se degringola num solipsismo (Descartes) e depois numa rejeição de uma subjetividade concreta (Hume, idealismo alemão, marxismo clássico). Porém, uma relação desprovida de subsistência (Ebner, Buber e Brunner) se mostra insustentável, devido à ausência de um núcleo gerador da relação e de um centro ao qual a relação deve se referir. O eu não é o resultado de uma somatória de atos pontuais, mas uma existência encarnada e situada. Sem consistência e subsistência, "o eu pessoal seria um sujeito evanescente e se converteria em pura vacuidade" (ZUBIRI, 1986, p. 108). 


\section{A dimensão teológica da pessoa humana}

A dimensão teológica da pessoa refere-se à sua relação com Deus. Se Deus é o fundamento do ser pessoal do ser humano, logo preconizar a morte de Deus, como fizeram alguns filósofos (F. Nietzsche) e teólogos (teologia da morte de Deus), significa proclamar a morte do sujeito, como defendeu alguns filósofos estruturalistas (L. Althusser, Lévi-Strauss e M. Foucault). Um eclipse na ideia de Deus causaria crise na compreensão do ser humano. A relação com Deus é constitutiva do ser pessoal do ser humano. Esta relação antecede a relação do ser humano com o mundo e com o tu humano. A relação do ser humano com Deus funda o seu ser pessoal, a sua mundanidade e a sua sociabilidade. Esta tríplice dimensão relacional está presente na visão bíblica do ser humano. Destas dimensões, a mais relevante e fundante é a relação do ser humano com Deus. O ser humano não é uma realidade auto-explicativa, mas deve ser compreendido e interpretado à luz do mistério Deus. A dignidade do ser humano tem sua origem em Deus. Em razão deste fundamento divino, a pessoa é possuidora de um valor absoluto.

\subsection{A relação dialógica entre Deus e a pessoa humana}

Uma antropologia cristã refuta o rebaixamento do ser humano ao nível animalesco, maquinal, coisista e biologicista. A fé cristã anuncia um uníssono “não” a esta perspectiva anacrônica, apresentando, através da categoria "imagem de Deus", a reciprocidade existente entre o ser humano e Deus. Esta categoria é irrenunciável para a antropologia cristã, visto que sem a mesma seria possível anunciar a morte do homem.

Deus não é uma magnitude indiferente, apática, alheia ou estranha ao ser humano. Deus não é uma realidade totalmente outra, como se fosse um ser inacessível e absolutamente transcendente em relação ao mundo e ao ser humano. Analogamente, o ser humano não é uma realidade desconhecida, anônima e 
impessoal para Deus. Entre ambas magnitudes não há um desconhecimento recíproco. Entre Deus e o ser humano não há inimizade, concorrência ou competitividade, porque ambos estão implicados, referidos e ordenados um para o outro. A afirmação de um não significa a negação do outro. Os dois se afirmam simultaneamente. Deus não é uma ameaça para a autonomia e a liberdade do ser humano. Um não pode ser compreendido sem o outro. Entre Deus e o ser humano, há uma relação interpessoal. Criando o ser humano à sua imagem, Deus já está se autorevelando. A criação é reveladora do ser de Deus. É se percebendo como um ser criado por Deus, que o ser humano se autocompreende. Na relação com o ser humano, Deus não é uma realidade impessoal, sem rosto, escondida atrás de um véu, nem uma terceira pessoa (um ele ou um outro) ou sujeito oculto, mas uma segunda pessoa, um tu. Trata-se de uma relação, pautada na segunda pessoa, entre dois seres pessoais, salvaguardando o desnível ontológico entre eles: um tu transcendente e um tu imanente. Esta relação mostra que entre Deus e o ser humano há uma relação mútua e recíproca. Se Deus fosse um senhor feudal, uma autoridade divina totalitarista, ditatorial e arrogante, não haveria possibilidade de uma afirmação recíproca. Caso fosse indigno de Deus ocupar-se com os mortais não seria possível uma relação mútua com o ser humano e, consequentemente, nem com o mundo. Se isso fosse possível, o ser humano poderia pleitear uma autoafirmação à margem de Deus. Se fosse indigno de Deus ocupar-se dos mortais também seria indigno dos mortais interessar-se por Deus. Os dois seriam duas realidades heterogêneas e detentores de uma autonomia absoluta. Eles habitariam dois mundos absolutamente distintos. No entanto, a escritura mostra que entre Deus e o ser humano reina uma relação de comunhão. A relação entre Deus e o ser humano não está pautada numa rivalidade, mas na dialética do tu-eu, que conduz para o nós. Deus e o ser humano se realizam, amando-se, acolhendo-se, abraçandose e respeitando-se, mediante uma relação dialogalmente compartilhada (RUIZ DE LA PEÑA, 1988, p. 176-177). Nesta dinâmica relacional, “o homem necessita do encontro com Deus; e Deus procura o diálogo com o homem" (FLICK; ALSZEGHY, 1971, p. 58). O ser humano não é uma instância existencial aprisionada em si 
mesma, mas possui um fundamento teológico. Isto refuta todo humanismo ateu de L. Feuerbach, de E. Bloch e outros.

Independentemente da condição espiritual (graça ou pecado), o ser humano está em relação e comunhão com Deus. É a partir do encontro com Deus que o ser humano surge e acontece. Sem a relação com Deus, o ser humano permaneceria estacionado em sua condição natural e não emergiria o seu ser pessoal. Mas, é pela mediação da relação com Deus, um ser pessoal, que o ser humano adquire personalidade. É a relação com Deus que possibilita ao ser humano transcender a sua dimensão natural e se tornar uma pessoa. Nenhuma outra instância (um animal, os objetos, as ideias) seria capaz de conferir personalidade ao ser humano. É próprio de um ser pessoal abrir-se a um tu realizar-se, entregando-se e projetando-se para fora de si. No horizonte bíblico, o mundo, o animal e as plantas não são um tu para o ser humano (Adão). O tu do ser humano é Deus e o tu de Deus é o ser humano. Deus quando cria o ser humano cria um tu com o qual relacionar-se. Deus é o tu primordial, fundante e basilar do ser humano.

É, de certo modo, a relação ontológica com o tu, a relação existencial, original. E ela é relação pessoal, pois se concretiza no apelo de amor. Deus me chama como o seu tu, a fim de que eu também possa chamá-lo de tu. Toda a minha vida é um perceber continuado deste apelo, a fim de que eu sempre lhe responda. Meu ser pessoal é ser-resposta, ou melhor, eu me torno cada vez mais pessoa à medida que correspondo ao apelo desta palavra com minha resposta de amor (SCHÜTZ; SARACH, 1973, p. 81).

O ser humano é um tu para Deus. Encontra-se arraigado no ser humano, como criatura chamada à existência por Deus, uma predisposição e uma abertura constitutivas para a relação com Deus. A criatura está, naturalmente, ordenada para o criador. Em razão de sua criaturidade, esta ordenação do ser humano para uma comunhão com Deus se verifica ainda que ela não passe pelo crivo da consciência e da razão. O ser humano é um tu para Deus porque é capaz de posicionar-se e dialogar com ele. Deus, chamando o ser humano à existência, cria um ser finito com quem pode dialogar para fora dele mesmo. O Deus cristão, além de ser um tu para si mesmo, cria um ser finito à sua imagem com quem estabelece 
uma relação interpessoal. A imagem está orientada para o seu Protótipo e para a sua Fonte. A imagem-cópia, o ser humano, é um tu para a imagem-modelo, Deus. O ser humano é criado com as condições de possibilidade para a relação com Deus. A relação do ser humano com Deus não é fruto de uma ascensão racional e nem de um autotranscendimento pessoal. O ser humano vive a procura de Deus porque recebeu dele a sua existência como uma oferta e um dom. O desejo do Absoluto pessoal, presente no ser humano, é porque Deus quando o criou o fez com esta potencialidade. O ser humano é uma existência com uma orientação para o sobrenatural.

A relação entre o ser humano e Deus é de "mão dupla": tu-a-tu. Deus é um tu para o ser humano. Deus é um tu para si mesmo e um tu para o ser humano. Deus, quando cria o ser humano, se reconhece, se percebe contemplado e refletido nele. $\mathrm{O}$ chamado do ser humano à existência não é genérico e nem impessoal, mas personalizado. O ser humano (Adão) não é uma criatura a mais ou uma natureza entre outras, mas um tu de quem Deus espera resposta. O ser humano é o ser capaz de dar uma resposta (responsabilidade) a Deus, porque é o único ser criado capaz de ser um tu para Deus. Nascido de uma palavra expressa por Deus (Gn 1,26), somente o ser humano pode dar e ser uma resposta ao criador. O ser humano é a única criatura capaz de responder à interpelação divina. Esta capacidade de resposta significa acolher (graça) ou rejeitar (pecado) a relação com o criador. Deus não espera uma resposta dos animais, das plantas e nem das demais criaturas, mas do ser humano, porque foi criado para fazer comunhão com ele. Deus cria o ser humano elegendo-o, chamando-o e interpelando-o a uma responsabilidade (capacidade de responder) e a uma correspondência. O ser humano não é um objeto ou uma marionete nas mãos divinas, mas um sujeito, interlocutor de um diálogo interpessoal e um ser capaz de se posicionar diante de Deus. O ser humano é a criatura com quem Deus estabelece uma relação de correspondência, de mutualidade e de reciprocidade. O que existe entre o ser humano e Deus não é uma aliança entre estranhos ou um contrato de tolerância mútua, mas uma relação dialogal, personalizante, respeitosa e responsorial. Em suma, o ser dador de 
resposta e o ser-resposta é uma pessoa (ser capaz de dispor-se de si), portadora de dignidade, respeito, valor, capaz de escutar o chamado e de responder livremente a Deus, estabelecendo, entre ambos, uma relação dialógica (LADARIA, 1998, p. 7071; SCHÜTZ; SARACH, 1973, p. 80-81; SCHEFFCZYK, 1976, p. 54-61; TOCQUER, 1960, p. 18; BOASSO, 1989, p. 88-89; RUBIO, 2001, p. 310-313; GUARDINI, 1963, p. 183).

\subsection{A dimensão axiológica da pessoa humana}

O ser criado à imagem de Deus, chamado a compartilhar uma relação dialógica com ele, porta uma dignidade absoluta, um caráter irrepetível e único, uma grandeza insubstituível e inconfundível, um respeito incondicional e um valor supremo. Toda pessoa humana, independentemente de seu status, raça, gênero, orientação sexual, nacionalidade e condição financeira, é possuidora de um primado onto-axiológico, em relação às demais criaturas. O ser humano, por seu fundamento teológico, ontológico e axiológico, ocupa o topo da pirâmide da realidade. Ele ocupa o cume do real porque é mais e vale mais do que qualquer outra realidade. Esta constatação teológica não consiste em rejeitar ou negar o valor existente nas outras criaturas, mas em reconhecer, que o ser humano na sua singularidade, concretude e unicidade é um ser criado segundo a imagem que Deus tem de si mesmo como fim e não meio. "Podemos dispor acerca das coisas, mas jamais da pessoa, que nunca pode ser considerada como meio para algo, mas como fim em si mesma" (VILLA, 2000, p. 597). A pessoa tem, em si mesma, a sua própria finalidade, ou seja, está objetivamente referida a si mesma. No seu agir, o ser humano se autorrealiza como ser pessoal. Por sua qualidade pessoal, a dimensão axiológica que o ser humano possui não lhe permite ser colocado em função da produção, de uma classe social, do Estado, da sociedade, da religião, enfim, de nada. O ser humano não pode ser instrumentalizado e nem manipulado por nenhuma estrutura ou instituição. Ele não pode ser utilizado, como uma realida de mediadora, para sustentar um sistema econômico, político, social e nem 
religioso. Ele não pode ser sacrificado, em sua condição pessoal, para servir a um fim (RUBIO, 2001, p. 308). Há um primado onto-axiológico da pessoa em relação às estruturas sociais, que são um meio. Ou seja, há um primado do pessoal sobre o estrutural, o social, o econômico e outros. A pessoa humana é anterior às instituições sociais e às leis, as quais devem estar ao seu serviço (Mc 2,27: "o sábado é para o homem e não o homem para o sábado”). A absolutização das instituições pode conduzir a uma relativização da pessoa, provocando uma subversão dos valores. Toda ação que instrumentaliza, escraviza e manipula a pessoa humana, avilta o seu valor e a sua dignidade. Esta postura é refutada pela antropologia cristã.

A pessoa não é simplesmente um exemplar da espécie humana e nem um puro caso particular de uma realidade universal, mas uma magnitude inédita e portadora de uma "existência rica e elevada que a faz superexistir espiritualmente em conhecimento e amor" (MARITAIN, 1967, p. 16). Ela não é fruto de uma produção em série, mas uma realidade singular e exclusiva. Não pode ser vista como deduzida ou derivada de algo, porque é detentora de uma originalidade e individualidade. "Afirmar, pois, que o homem é sujeito e pessoa significa primeiramente que o homem tem algo de irredutível, que não se pode produzir completamente a partir de outros elementos a nós disponíveis. Ele é o ser que está sempre entregue à responsabilidade por si mesmo" (RAHNER, 1989, p. 45). Uma pessoa não é resultado de uma manipulação ou de uma duplicação genéticas. Ela não pode ser fabricada geneticamente. Se uma pessoa fosse resultado de uma construção genética, poderia ser transformada em meio para fins escusos. "A pessoa humana, em seu ser e em sua própria dignidade, reivindica um respeito incondicional, independente de toda livre valorização e finalidade; absoluto, numa palavra" (RAHNER, 2002, p. 241).

O ser humano é um fim, que está ordenado a um fim superior (Deus). Sem este fundamento teológico, o postulado de sua dignidade e de seu valor absoluto, dificilmente, teria sustentabilidade. Pela sua relação com Deus, o ser humano 
possui uma dignidade, que já lhe é conferida de modo antecipado, como ponto de partida e missão. A dignidade do ser humano participa da dignidade de Deus.

\begin{abstract}
A realização, a apropriação e a custódia da dignidade dada de antemão constitui a última e definitiva dignidade do homem [...] Enquanto esta essência [da dignidade humana] provém de Deus e se dirige a Deus, recebe dele e a ele se abre, é de tal natureza que a dignidade que leva consigo é por sua vez o mais íntimo dela e algo superior a ela; portanto, participa do inacessível, do misterioso e do inefável de Deus, e só se revela plenamente em um diálogo do homem com Deus (por conseguinte, fé e amor) e, por conseguinte, não se apresenta nunca à maneira de um objeto tangível (RAHNER, 2002, p. 234).
\end{abstract}

Deus está na origem e do destino do ser humano. Por isso, o ser humano provém e está orientado para Deus.

"A pessoa tem uma dignidade absoluta porquanto está em uma relação direta com o absoluto, no qual ela pode encontrar sua plena realização" (MARITAIN, 1967, p. 17). O fundamento ontológico e axiológico do ser humano está em Deus, o seu fim supremo. A ausência do fundamento divino do ser humano o destituiria de sua dimensão pessoal e o reduziria à sua condição natural. O ser humano é uma unidade dialética de natureza e de pessoa (RAHNER, 2000, p. 364, nota 14; SAYÉS, 2002, p. 214-216; MÜLLER; HALDER, 1974, p. 448-450). A natureza refere-se à realidade previamente dada. É aquilo que o ser humano é. A natureza é a realidade que possibilita o surgimento da pessoa. A pessoa é o ser humano, enquanto decide sobre si mesmo, dispondo-se livremente de si mesmo, na medida em que possui sua própria realidade definitiva. É a capacidade que o ser humano possui de eleger, optar e decidir sobre si mesmo. A pessoa é aquilo que o ser humano é chamado a ser e a tornar-se. O ser humano é uma natureza chamada a ser pessoa. A condição pessoal do ser humano, não é uma realidade acabada, mas a caminho, um homo viator. O ser-pessoa é um devir ontológico que ocorre na medida em que me relaciono com o meu próximo. Eu me torno mais pessoa, na proporção em que me compreendo mais relacionado com o tu. O devir da pessoa é uma contínua autossuperação e autotranscendência, porque o ser humano é uma realidade em constante criação (SCHÜTZ; SARACH, 1973, p. 84). Caso o ser 
humano fosse destituído de sua condição pessoal seria relegado a uma partícula da natureza, o anonimato da espécie e não teria um plus qualitativo. O ser humano seria reduzido à mesma condição ontológica das demais criaturas. Assim, a realidade gozaria de uma constante ontológica única. A realidade não seria plural e nem heterogênea, mas ontologicamente homogênea e uniforme.

Devido à sua condição contingente, finita e limitada, o ser humano não pode postular um caráter absoluto à margem de Deus. O ser humano é um ser afetado por um crônico coeficiente de nulidade ontológica. Caso o ser humano tivesse a razão de ser em si mesmo e para si mesmo, o seu valor estaria relegado à cotação de qualquer bem efêmero. $\mathrm{O}$ ser humano não pode ser reduzido à condição de uma peça, que faz um sistema funcionar, nem de uma mercadoria, nem de uma função e nem à sua dimensão material e carnal. A sua condição pessoal não lhe permite ser reduzido a nenhuma instância (RUIZ DE LA PEÑA, 1988, p. 178-179). Se o ser humano prescindisse de seu fundamento verdadeiro, se tornaria uma carne perecível, "uma flor que se abre e logo murcha" (Jó 14,2). Através da constatação do caráter dramático e vulnerável da existência humana, o filósofo existencialista francês J.P. Sartre (2011, p. 750) definiu o ser humano como uma "paixão inútil".

A antropologia cristã reconhece a proeminência axiológica do ser humano, a qual é incompatível com um antropocentrismo absoluto, para o qual o sujeito é concebido como centro e fim absoluto, independente de sua abertura ao tu divino. O ser humano não é um fim em si mesmo à margem de Deus. Se o antropocentrismo absoluto tivesse validade, a dimensão transcendental do ser humano seria fruto de uma conquista da razão e não de sua existência como dom. Mas, para a fé cristã, o fundamento teológico do ser humano é dádiva divina e não mérito da racionalidade. A pessoa humana é um "absoluto relativo [...] que se encontra remetida a uma realidade-fundamento, absolutamente absoluta", que é Deus (ZUBIRI, 1984, p. 308.316). O fundamento do absoluto relativo está no Absoluto absoluto e legitima o valor supremo, a dimensão moral e a dignidade absoluta da pessoa. É nesta condição de ser-orientado-para-Deus que situa a raiz 
da personalidade humana. O fundamento da condição de ser-para-Deus do ser humano está no fato de que Deus o criou com esta potencialidade. É neste ordenamento divino do ser humano que está a inviolabilidade da sua dignidade e do seu valor.

É na encarnação de Jesus Cristo que se ratifica, definitivamente, o valor supremo da pessoa humana. Na encarnação, Deus assume a carne humana para conduzi-la à perfeição e à divinização. A dignidade humana é assumida por Deus e elevada ao seu grau máximo de realização e de reconhecimento. Jesus assumiu e plenificou a dignidade e o valor de toda e cada pessoa humana. O valor de toda pessoa humana é igual, pois cada uma tem um fundamento divino.

\subsection{Deus como fundamento da relação interpessoal}

Até o momento se refletiu sobre o aspecto pessoal do ser humano, cuja fundamentação está na sua relação com Deus. Esta abertura transcendental do ser humano para Deus tem uma fundamentação bíblica e não constitui um mecanismo de alienação ou escapista. A vocação transcendental do ser humano reside no fato de que ele foi criado por Deus com este ordenamento. A relação do ser humano com Deus passa, necessariamente, pela mediação do outro. Uma relação com Deus que não passa pela mediação do outro pode ser alienante. A abertura do ser humano para a comunhão com Deus se realiza e ganha concretude e visibilidade, pela mediação do tu humano. A relação entre o ser humano e Deus não permanece confinada somente entre os dois, mas se abre para um terceiro sujeito. Assim, há uma triangulação relacional entre Deus, eu e o outro. O próximo é um caminho necessário, pelo qual se deve passar, para um diálogo plenificante com Deus. A relação com o outro é um reflexo da comunhão entre Deus e o ser humano. A pessoa é compreendida pela intercomunicação criadora e amorosa com Deus e com os outros. Deus é o fundamento do ser pessoal e interpessoal do ser humano. O fato de o Deus cristão ser comunicação e diálogo, entre as pessoas divinas, constitui o fundamento da dimensão social e interpessoal da pessoa. Como Deus é diálogo, 
assim, o ser criado à imagem de Deus já tem uma vocação natural para a relação interpessoal com o outro (WERBICK,1993, p. 683). A condição pessoal do ser humano reside na sua capacidade de apropriar-se de si mesmo enquanto tal, sendo simultaneamente disponível, mediante uma relação consciente e livre com a realidade (mundo, outro) e com Deus (PERSONA, 1968, p. 500).

A pessoa não tem o fundamento último de seu existir em si mesma. Ela não é uma consciência pura, irrelacional, descorporificada, confinada e nem fechada em si mesma. Não é uma subjetividade solitária e encarcerada numa prisão solipsista de seu próprio eu. O ser humano se autorreconhece como eu diante de um tu. A pessoa é um eu, o núcleo fundante de sua autoconsciência e de sua identidade, que está em comunhão e relação com outros eus, que são os tus, os seus semelhantes. O eu, necessariamente, implica um tu. Só posso dizer eu na medida em que estou relacionado com um tu. $\mathrm{O}$ eu se realiza através da relação com um tu. A pessoa é uma subjetividade interpelada e relacionada com outras subjetividades, ou seja, é intersubjetividade (VILLA, 2000, p. 597). A "pessoa expressa o ser mais íntimo de cada homem, o seu eu, enquanto não consegue entender-se a não ser numa correlação mútua com o tu" (SCHÜTZ; SARACH, 1973, p. 87-88).

O ser-pessoa fundamenta-se em Deus e se realiza no âmbito interpessoal. A garantia de que o ser humano é capaz de manter uma relação amorosa com Deus, escutando-o e respondendo-lhe, verifica-se no fato de se relacionar e se comunicar amorosamente com o seu próximo. O ser humano é alteridade, abertura comunicativa e dialogia na relação com Deus e com o próximo. A abertura ao Grande Outro supõe uma abertura ao outro, imagem e visibilidade de Deus: "Se alguém disser: 'amo a Deus, mas odeia o seu irmão, é um mentiroso: pois quem não ama seu irmão, a quem vê, a Deus, a quem não vê, não poderá amar [...] aquele que ama a Deus, ame também o seu irmão" (1Jo 4,20-21). O outro é tão imagem de Deus quanto eu o sou e por isso ele é revestido da mesma dignidade e consideração. "Porque são criados por Deus e porque são dotados das mesmas qualidades, características e fundamentos, todos os membros do gênero humano são dignos da 
máxima consideração" (COMISSÃO TEOLÓGICA INTERNACIONAL, 2006, p. 263). A minha relação com o outro é uma analogia da minha relação com Deus e a minha relação com Deus é uma analogia da minha relação com o próximo. Aquele que ama, respeita, aceita e reconhece o outro, que é imagem de Deus, é capaz de amar, respeitar e aceitar a Deus, ainda que de modo atemático e irreflexo. Contrariamente, aquele que rejeita, odeia e nega o outro, imagem de Deus, indiretamente, nega e rejeita a Deus, ainda que o confesse teoricamente. Um olhar que vai além do plano físico e biológico, sendo capaz de perceber a profundidade, a originalidade e a dignidade do ser pessoal do ser humano, imagem de Deus, direta ou indiretamente, faz uma confissão de fé cristã. Em contrapartida, um olhar objetivante, cientificista, coisificador e materialista é um ato de incredulidade. Quem não contempla ou não percebe o rosto de Deus que se descortina em sua imagem, o ser humano, não enxerga a presença de Deus na realidade. O amor do ser humano por Aquele que ele não vê concretiza-se no rosto daquele que ele vê, o seu próximo. A aceitação ou a rejeição do outro, do ponto de vista prático, pode conduzir a um cristianismo anônimo ou a um ateísmo anônimo. A afirmação ou a rejeição do outro tem consequências na relação com Deus (RUIZ DE LA PEÑA, 1988, p. 180-181).

$\mathrm{Na}$ visão da antropologia cristã, uma afirmação genuína do outro, tão imagem de Deus o quanto eu sou, consiste em uma afirmação do tu divino. A afirmação do valor supremo do outro não é uma certificação empírica, fenomênica e cientificista. A certificação empírica do outro constata a sua finitude e contingência. Uma visão puramente fenomenológica não capta a dimensão teologal e axiológica do ser humano. A percepção do valor absoluto do ser humano exige que se dê um salto qualitativo para além do plano fenomenológico, físico e empírico. Para captar a dimensão pessoal e espiritual do ser humano, é necessário transcender uma visão puramente natural, aparencial e material sobre ele.

A fé cristã é capaz de transcender uma visão puramente material, ultrapassando um olhar simplesmente epidérmico sobre o ser humano e chegar até 
as vísceras, quer dizer, ela é capaz de ir além das aparências e perceber a realidade que se encontra no subsolo delas. À luz da fé cristã, é possível perceber a dimensão pessoal, espiritual e mistérica do ser humano. O amor ao próximo, como um perfeito e amadurecido ato de fé, denota "abertura e acolhida da realidade misteriosa do absoluto criado, sinal, sacramento e imagem do Absoluto incriado" (RUIZ DE LA PEÑA, 1988, p. 181). O ser humano "se faz pessoa plenamente quando supera sua própria natureza dando a sua vida não só por seus amigos, mas também por seus inimigos" (CLÉMENT,1972, p. 48-49).

Deus não é uma magnitude intermediária entre eu e meu próximo, como se a condição de possibilidade de se amar o próximo fosse plausível somente pelo amor a Deus. O amor ao próximo não pode ser visto como uma imposição do amor a Deus. O reconhecimento de Deus, como doador da vida humana, leva o ser humano a contemplar e a amar o tu imanente como um próximo e, à luz da fé cristã, como um irmão. É relacionando-me com o outro e vendo-o como imagem do Deus, de quem também sou imagem, é que me abro, cada vez mais, para uma relação amorosa com ele. O mesmo Deus que me criou também criou o meu próximo de modo que tanto a minha vida quanto a dele tem um valor supremo.

O homem se reconhece a cada momento como aquele que é criado por Deus através do próximo [...] eu me compreendo cada vez mais, respondo cada vez melhor ao apelo criador de Deus, que é meu fundamento, quando me entendo no amor, por meio e por força de todas as relações pessoais, que se constituem em forma dialogal a partir do próximo (SCHÜTZ; SARACH, 1973, p. 81).

A relação do ser humano com Deus é mediada pela relação com o tu humano. A relação com Deus ocorre por mediações. De forma semelhante, a relação de Deus com os seres humanos se dá pela mediação da encarnação de Jesus Cristo. Deus age no mundo pelas mediações, ou como a teologia clássica dizia, pelas causas segundas. Já, a relação com o outro, a relação interpessoal, é direta e não-mediatizável. A minha relação com o outro é imediata. Assim, a relação mediata com Deus passa pela relação direta com o outro. 
A relação com Deus funda a personalidade do ser humano e salvaguarda a referência ao tu humano como relação interpessoal. Todo ser humano, imagem de Deus, é igual porque tem Deus como realidade-fundante de seu ser pessoal. Não sou eu que outorgo o caráter pessoal ao outro, mas Deus, que primeiramente se dirigiu a ele e fundou sua personalidade. Não sou eu que transformo o outro de objeto à pessoa. Antes que eu me dirija ao outro, este já é pessoa e um tu com quem posso estabelecer uma relação interpessoal. A constituição pessoal do outro é anterior à minha relação e encontro com ele. Eu e o outro já temos uma constituição pessoal antes de qualquer relação ou encontro. É esta constituição que funda a condição de possibilidade de uma relação interpessoal. Caso Deus não fosse o fundador da dignidade pessoal do outro, não haveria uma igualdade axiológica entre os seres humanos, dando margem para uma relação objetal e coisista com o tu humano. Se eu me percebesse como valor supremo e se eu não reconhecesse no outro este capital teológico, esta constatação poderia induzir-me a fazer do outro um instrumento para atingir meus interesses econômicos, políticos e outros. Caso isso fosse possível não justificaria amá-lo, porque o mandamento que entraria em vigor seria do amor próprio. Esta perspectiva desembocaria em uma espécie de darwinismo antropológico, com a vigência da lei do mais forte. As relações inter-humanas seriam marcadas pela concorrência, rivalidade e competitividade. O outro seria visto não como um tu (companheiro, colaborador), mas como um adversário. Assim, o ser humano seria reduzido a uma realidade infrapessoal.

À margem de Deus, realidade-fundante do ser pessoal do ser humano, haveria um real perigo do ser humano ser instrumentalizado, sacrificado, mediatizado e destituído de seu valor absoluto, em função de fins desumanos. Segundo F. Dostoiévski, “se Deus não existe, tudo é permitido” e, assim, se justificariam as arbitrariedades e as barbaridades cometidas contra o ser humano, posto que seria a falência de sua dignidade e inviolabilidade (RUIZ DE LA PEÑA, 1995, p. 216-217). Sem Deus, a criação, o ser humano e a ética seriam destituídos de 
seu fundamento último. É na asserção de Dostoiévski que se apóiam o humanismo ateu e os ensaios de uma ética laica (DE LUBAC, 2008; ALFARO, 2002)ํ․

Contudo, se Deus existe, então, são injustificáveis quaisquer barbáries e arbitrariedades cometidas contra o próximo, que é possuidor de um valor absoluto, que transcende interesses pessoais em querer manipulá-lo. O próximo é uma criatura chamada à existência, amada incondicionalmente e escolhida pessoalmente por Deus como seu tu, seu parceiro. Por isso, a dignidade deste ser pessoal é inviolável e seu capital espiritual é supremo. A existência de Deus faz com que o ser humano perceba a gratuidade de sua existência. É na autodoação de Deus que o ser humano se realiza pessoalmente. Reconhecendo a sua vida como um dom, o ser humano é capaz de vivê-la, como livre autodoação, reproduzindo a atitude divina. Assim, o ser humano como tem uma origem divina, logo deve ser para os demais. A existência humana é um dom que se realiza como entrega, oferta e disposição. A pessoa é um sinônimo de disponibilidade. Só posso compreenderme como fruto do amor gracioso de Deus e ser fiel a este gesto divino, quando eu amar e tornar-me disponível para o próximo, portador do mesmo valor absoluto que eu (RUIZ DE LA PEÑA, 1988, p. 182-183). O próximo é um companheiro e não um rival; um irmão e não uma existência anônima; um tu e não uma instância impessoal; uma pessoa e não um objeto. O ser humano é um território sagrado, que não pode ser invadido e merecedor do mesmo respeito que se devota a Deus. O mesmo respeito e amor que se tem por Deus deve-se ter pela sua imagem, o ser humano. Sabe-se da devoção, que uma pessoa tem por Deus, pela forma como ela se relaciona com o seu próximo. Violar a dignidade do ser humano consiste em violar a majestade de Deus. O ser humano é uma realidade abreviada daquilo que Deus é. "O homem é maneira finita de ser Deus" (ZUBIRI, 1984, p. 327). Deus é a experiência do ser humano e o ser humano é a experiência de Deus.

\footnotetext{
${ }^{1}$ Sartre refuta a afirmação de Dostoiévski. Para o filósofo francês, o absoluto é produzido pelo relativo. Deus não existe e tudo é permitido, logo o ser humano deve decidir sobre seu próprio ser (INVITTO, 1998, p. 417).
} 
A valorização da pessoa e sua dimensão não-mediatizável são pontos de confluência entre as antropologias humanistas (por exemplo, o humanismo marxista de E. Bloch e R. Garaudy) e o cristianismo. Na visão cristã, o encontro da experiência recíproca entre o ser humano e Deus se deu plenamente na encarnação. Jesus é o ponto de encontro entre Deus e os seres humanos. Ele é Deus para nós e nós para Deus. Para a fé cristã, a encarnação levou até as últimas conseqüências a intuição humanista de que o ser humano é o ser supremo para o ser humano e para Deus, demonstrando a existência de uma dimensão ética, que perpassa as relações humanas orientadas pela dignidade pessoal de cada pessoa. Esta visão se contrapõe a todas as perspectivas (coisificação, objetificação e reducionismos) que infravalorizam o ser humano.

Como tenho de tratar meu próximo e por quê? "Cada homem tem de ser tratado como Deus, porque Deus quis ser e deixar-se tratar como homem" (RUIZ DE LA PEÑA, 1988, p. 184). A encarnação de Deus não viola a integridade do ser humano, mas a eleva em sua dignidade e valor. Deus desce para que o ser humano se eleve. A encarnação é sinônimo de humanização e de convite ao ser humano para que se torne Deus. "Deus criou o homem na perspectiva da divinohumanidade" (CLÉMENT, 1972, p. 50). Para a fé cristã, o destino do ser humano é ser como Cristo, o ser humano realizado. A antropologia cristã é uma cristologia a caminho. A antropologia cristã tem o seu desfecho na cristologia. Cristo é o princípio e o fim daquilo que o ser humano é chamado a ser (RAHNER, 1972, p. 17). O ser humano tem como escopo de seu percurso antropológico a divinização pela mediação de Cristo. Esta realização humana suprema é uma possibilidade conferida por Deus ao criar o ser humano com as condições necessárias para alcançar o seu apogeu em Cristo. O ser humano será mais humano quanto mais próximo de Cristo estiver. Cristo constitui o paradigma da realização humana. A realização desta possibilidade, ser como Cristo, é uma consumação do projeto do que constitui o ser humano. Na medida em que o projeto humano progride, na sua realização em Cristo, evolui em sua liberdade. A realização do ser humano em Cristo é a consumação de sua liberdade pessoal. Deus é um mistério, cuja 
autocomunicação se deu em Cristo. O mistério de Cristo ilumina o mistério do ser humano. Assim, Deus, Cristo e o ser humano são realidades mistéricas.

\section{A pessoa humana é uma realidade indefinível e mistérica}

Definir significa delimitar, enquadrar e estabelecer limites. A definição enquadra uma realidade dentro de limites. Uma realidade definida se move dentro de uma circunscrição teórica. Definir é dar a conhecer. É esclarecer e dominar. Deste modo, será que uma pessoa pode ser objeto de uma definição cabal? A pessoa é uma realidade pluridimensional, por sua condição histórica, social, livre, corpórea, orgânica, cultural, sexuada, anímica etc., que não pode ser enquadrada em uma definição. "Uma só expressão não pode encerrar em si uma realidade tão aberta e rica como a pessoa" (VILLA, 2000, p. 597). Definir a pessoa significa reduzi-la a um conceito. É praticamente impossível confinar a diversidade constitutiva da pessoa a um conceito. Dificilmente uma definição abarcará a totalidade daquilo que a pessoa é. Igualmente, difícil seria uma definição sobre a pessoa que gozasse de uma aceitação de todas as ciências (antropologia, filosofia, sociologia, psicologia, medicina etc.). Cada ciência a contempla a partir de um método e um ponto de vista. A pessoa é estudada e analisada segundo a visão setorizada de cada ciência. Dificilmente uma ciência tem uma percepção da totalidade da complexidade da pessoa, visto que ela escapa de qualquer possibilidade de ser reduzida a um único olhar. Portanto, cada ciência tem algo de legítimo a dizer sobre a pessoa. No entanto, não há uma ciência que defina a pessoa esgotando a pluralidade de seus aspectos.

A indefinibilidade da pessoa é um reflexo da indefinibilidade de Deus. Assim como Deus escapa de qualquer possibilidade de ser conceituado e esgotado em sua constituição divina, o mesmo ocorre com a pessoa. Da mesma forma que é mais fácil dizer aquilo que Deus não é do que aquilo que ele é, algo análogo acontece com a pessoa. O caráter apofático no conhecimento de Deus é transferido para a pessoa. 
Assim como em Deus há uma superação constante diante da possibilidade de racionalizá-lo e teorizá-lo, algo semelhante sucede com a pessoa.

"Cada um de nós é portador de um grande mistério que é a personalidade humana" (MARITAIN, 1967, p. 16). A pessoa é um mistério e não um problema. Um problema exige uma solução. Uma realidade problemática reclama ser decifrada. A resolução coloca um ponto final no problema. Uma vez resolvido, o que era problemático, se torna esclarecido. A pessoa não é um problema porque não é uma realidade que possa ser decifrada e nem objetivada. Se a pessoa pudesse ser decifrada, de forma cabal, poderia ser definida e dominada. O mistério da pessoa está fora do alcance do conhecimento objetivo. A "pessoa não pode ser plenamente confinada numa definição porque a pessoa tem muito de mistério" (VALVERDE, 1995, p. 34). Não se pode esquadrinhá-la, racionalmente, porque é um mistério. "Um problema é, pois, algo que encontro diante de mim que posso objetivamente delimitar e reduzir. Um mistério é algo em que meu próprio ser está implicado e comprometido. Diante do problema minha atitude é a de um simples espectador: no mistério eu mesmo sou o ator" (GIORDANI, 1997, p. 120). "A pessoa é um mistério profundo porque é imune contra toda violação. Ela foge ao confronto em que seria reduzida a um objeto de contemplação. No instante em que se tenta transformá-la em objeto, deixa de ser pessoa. Ela nunca é 'objetivável'" (SCHÜTZ; SARACH, 1973, p. 88).

A pessoa é um mistério assim como Deus o é. O mistério da pessoa está orientado para o mistério de Deus. "O homem é, pois, em sua essência, em sua própria natureza, o mistério, não porque seja em si a plenitude infinita, que é inexaurível, do Mistério para o qual tende, mas antes porque ele, em sua essência autêntica, em seu fundo originário, em sua natureza é a referência" (RAHNER, 1989, p. 259). É próprio da pessoa, a sua referência ao Mistério incompreensível de Deus. Aqui, o significado do termo "mistério", no sentido conferido por Rahner (1970, p. 153-216), não significa uma realidade, que tem uma data de validade ou um caráter temporário que será desvelado, posteriormente. O mistério não é aquilo 
que a razão ainda não conhece e não decifra, mas o que futuramente será revelado. Não é o provisoriamente oculto, desconhecido e impenetrável. Mas, mistério é o indecifrável, o indefinível e o incompreensível. O mistério é aquilo que a razão não alcança, porque é inalcançável. É o inabarcável, o inabrangível, o inobjetivável e o incompreensível. O mistério tem uma validade permanente: sempre será mistério. Ele é compreensível, na sua incompreensibilidade, e definível, na sua indefinibilidade. Desta forma, a pessoa e Deus são mistérios permanentes. A pessoa é o mistério e Deus o Mistério Absoluto.

No plano fenomenológico, o caráter mistérico da pessoa não significa que ela é algo hermético e impenetrável. É possível ter um conhecimento aproximativo, porque a própria pessoa, também, é um mistério para si mesma. O que se pode conhecer de uma pessoa é aquilo que ela revela. Mas, a pessoa não revela tudo aquilo que ela é, nem para si e nem para os outros. "Sabemos muitas coisas sobre a pessoa, mas nunca as saberemos cabalmente e por completo, já que, à medida que a conhecemos, mais nos apercebemos de que ainda nos falta muito por conhecer, pois ela não pode ser apreendida como algo rijo e esclerótico" (VILLA, 2000, p. 598). Portanto, na pessoa, há sempre uma reserva de mistério.

\section{A pessoa humana na Constituição Pastoral Gaudim et Spes}

A Gaudim et Spes (GS), em sua primeira parte, trata, de forma sintética, de alguns dos principais temas da antropologia cristã como a dignidade da pessoa humana, a comunidade humana e o sentido da atividade humana. A nossa reflexão se concentrará em torno do tema da dignidade humana. A Constituição já indica na introdução, tratando do ser humano no mundo de hoje, qual é o foco de sua reflexão: "É a pessoa humana que deve ser salva. É a sociedade humana que deve

ser renovada. É, portanto, o homem considerado em sua unidade e totalidade, corpo e alma, coração e consciência, inteligência e vontade, que será o eixo de toda a nossa explanação" (GS 3,1). 
O Concílio recupera a relação entre a cristologia e a antropologia que era intensa na patrística e se atenuou nos períodos medieval e moderno. $\mathrm{O}$ fundamento da antropologia cristã é Cristo. O mistério de Cristo lança luz no mistério do ser humano. Cristo é a chave interpretativa do mistério do ser humano. A Constituição deseja, à luz de Cristo, "esclarecer o mistério do homem e cooperar na descoberta da solução dos principais problemas do nosso tempo" (GS 10,2). Os desafios do tempo presente estão relacionados com a pessoa humana. A evolução tecnocientífica, biotecnológica, o surgimento das máquinas inteligentes e a ascensão dos objetos provocaram uma crise antropológica, colocando em questão a identidade da pessoa humana (Quem é, afinal, o ser humano?).

Na visão da Constituição, a compreensão da identidade da pessoa tem como ponto de partida a definição bíblica do homem, como imagem de Deus ( $G S$ 12,3). O ser humano, por sua condição de imagem de Deus, tem uma centralidade criacional de modo que "todas as coisas existentes na terra são ordenadas ao homem como seu centro e ponto culminante" ( $G S$ 12,1). Se a pessoa é o ponto para o qual tudo converge, logo compreendê-la é a condição de possibilidade para se entender a realidade. Se o prólogo, para se esclarecer o mistério da identidade da pessoa, é Gn 1,26, então o epílogo é Cristo: "Na realidade, o mistério do homem só se torna claro verdadeiramente no mistério do Verbo Encarnado" ( $G S$ 22,1). Adão é o ponto de partida e Cristo é o ponto de chegada, na compreensão do ser humano. Sem Cristo, o mistério da pessoa permaneceria obscuro. O mistério de Cristo revela o mistério da pessoa. A pessoa encontra sua plenitude e realização em Cristo. A antropologia tem um destino cristológico. A cristologia é uma antropologia consumada. "Cristo manifesta plenamente o homem ao próprio homem e lhe descobre a sua altíssima vocação. Não é, portanto, de se admirar que em Cristo estas verdades encontrem sua fonte e atinjam seu ápice" ( $G S$ 22,1). Deus se autorrevelando em Cristo termina por revelar o ser humano a si mesmo. Através de Cristo, a pessoa se autoencontra e se autodescobre. Em Cristo, a vocação humana é desvelada: ser como Deus (divinização). Como todos os seres humanos têm a mesma natureza, origem e 
gozam da mesma vocação e destino, pela mediação de Cristo, logo há uma "igualdade fundamental entre todos" (GS 29,1).

"A razão última da dignidade humana consiste na vocação do homem para a comunhão com Deus. Já, desde sua origem o homem é convidado para o diálogo com Deus. Pois, o homem, se existe, é somente porque Deus o criou e isto por amor. Por amor é sempre conservado" (GS 19,1). O fundamento da dignidade da pessoa está na sua vocação para a relação interpessoal com Deus. Criando o ser humano, Deus cria um ser com quem pode estabelecer uma relação de tu a tu. Deus cria o ser humano orientado para a comunhão com ele. Esta comunhão, experimentada no plano terreno, será mantida no plano definitivo. "A semente de eternidade que [a pessoa] leva dentro de si [...] insurge-se contra a morte" (GS 18,1). A morte não significa a interrupção na comunhão entre a criatura e o criador, mas é o ponto de passagem, que dá continuidade a esta comunhão, em um novo plano de existência: a vida definitiva. A morte assinala a descontinuidade no plano de duração (passagem do plano terreno ao definitivo) e a continuidade da comunhão entre a pessoa e Deus. O ser criado por amor será arrancado das garras da morte, por Deus, por um ato de amor: é nisto que consiste a ressurreição.

Em razão de sua dignidade, expressa biblicamente por sua condição de imagem de Deus, o ser humano é "superior aos elementos materiais e não se considera uma partícula da natureza ou um elemento anônimo da cidade humana" $(G S$ 14,2). Esta superioridade reside no fato de que o ser humano é a única criatura criada à imagem de Deus. É uma superioridade qualitativa, em relação às demais criaturas. Por seu fundamento espiritual, o ser humano tem um salto ontoaxiológico, ou seja, é uma criatura que tem um quid plus em relação ao seu em torno. O ser humano não é uma realidade impessoal e anônima presente na criação, mas, por sua qualidade pessoal, é possuidor de um excedente, comparando-se com as outras criaturas. O ser humano é a única criatura que vive a procura da verdade, do amor e do bem. "Impregnado de sabedoria, o homem passa das coisas visíveis às invisíveis" $(G S 15,2)$. As coisas visíveis estão grávidas das 
invisíveis. O presente está prenhe de futuridade. O céu está sendo gestado na terra.

"A Igreja sustenta que o reconhecimento de Deus não se opõe de modo algum à dignidade do homem já que esta dignidade se fundamenta e se aperfeiçoa no próprio Deus" ( $G S$ 21,3). A afirmação de Deus não leva a uma negação do ser humano, assim como a afirmação da vida definitiva não conduz a uma negação da vida terrena. Mas, a afirmação de Deus é também a afirmação da criatura chamada à existência por Deus. Deus e o ser humano se afirmam simultaneamente. A afirmação do ser humano não consiste numa negação, mas numa afirmação de Deus. Afirmando o ser humano, afirma-se, indiretamente, aquele que o criou. Já, a negação de Deus destitui a pessoa de sua dignidade e, consequentemente, de sua fundamentação onto-axiológica. A negação de Deus destrona o ser humano de sua qualidade pessoal e o reduz à sua dimensão natural. Negando Deus, o ser humano nega a si mesmo. Assim, o ser humano permanece "para si mesmo um problema insolúvel" ( $G S$ 21, 4). Outras consequências da negação de Deus consistem no fato que os enigmas centrais da vida humana (a morte, a dor, a culpa) permanecem sem solução (GS 21,3). Por conseguinte, a existência humana está lançada ao desespero, à angústia e à tragicidade.

A encarnação consiste na afirmação do ser humano. Cristo, assumindo a condição humana, a eleva à sua máxima realização. "Como a natureza humana foi n'Ele assumida, não aniquilada, por isso mesmo também foi em nós elevada a uma dignidade sublime" ( $G S$ 22,2). Na encarnação, a natureza humana não é anulada, mas afirmada e exaltada. A humanização de Deus significa uma divinização do ser humano. O Deus cristão, diferentemente do que pensavam os gregos e o gnosticismo, não tem repudio do ser humano, nem da matéria e nem do corpo, mas com a encarnação estas realidades são assumidas e elevadas a uma excelsa dignidade. Com a encarnação, o ser humano, em sua contingência, finitude e limitação, é assumido em Deus. A natureza humana, assumida e exaltada, não é uma natureza idealizada, purificada de limitações, mas em sua realidade e concretude. Assumindo a condição humana, Deus se associou a todo ser humano e 
ao ser humano todo. "Com efeito, por Sua encarnação, o Filho de Deus uniu-se de algum modo a todo homem" (GS 22,2). Deus não se uniu somente a um sujeito individual, mas se associou a toda a natureza humana singularizada na humanidade de Cristo. É unindo-se a todo ser humano, que Deus pode salvar todo ser humano. É assumindo a natureza de todos e morrendo por todos é que Deus, em Cristo, pode salvar a todos.

A pessoa humana, em virtude de sua "dignidade exímia", goza de

direitos e deveres que são universais e invioláveis. É preciso, portanto, que se tornem acessíveis ao homem todas aquelas coisas que lhe são necessárias para levar uma vida verdadeiramente humana. Tais são: alimento, roupa, habitação, direito de escolher livremente o estado de vida e de constituir família, direito à educação, ao trabalho, à boa fama, ao respeito, à conveniente formação, direito de agir segundo a norma reta de sua consciência, direito à proteção da vida particular e à justa liberdade, também em matéria religiosa $(G S 26,2)$.

A dignidade humana é o princípio fundante que torna a pessoa portadora de direitos universais. A dignidade é o princípio que unifica, humanamente, todas as pessoas.

\begin{abstract}
Ainda que haja entre os homens justas diferenças, a igual dignidade das pessoas postula que se chegue a uma condição de vida mais humana e mais equitativa. Pois, as excessivas desigualdades econômicas e sociais entre os membros e povos da única família humana provocam escândalo e são contrárias à justiça social, à equidade, à dignidade da pessoa humana e à paz social e internacional (GS 29,3).
\end{abstract}

A existência de diferenças sociais, culturais, políticas e religiosas entre as pessoas não afeta a igualdade e a dignidade que há entre elas. A dignidade humana não está na função, no cargo ou no papel social, que uma pessoa exerce, mas está na pessoa que exerce o ofício, independentemente de quem seja. Não há uma hierarquia de dignidade, porque humanamente não há uma hierarquia entre as pessoas. Toda ação, que afeta a dignidade e os direitos básicos da pessoa, atinge o coração de Deus. "Contudo qualquer forma de discriminação nos direitos fundamentais da pessoa, seja ela social ou cultural, ou funde-se no sexo, raça, cor, 
condição social, língua ou religião deve ser superada e eliminada, porque contrária ao plano de Deus" (GS 29, 2). Toda ofensa à criatura é uma ofensa ao criador.

"A dignidade pessoal e a liberdade do homem não podem ser adequadamente asseguradas por nenhuma lei humana como o são pelo Evangelho de Cristo confiado à Igreja" ( $G S$ 41,2). A dignidade e a liberdade são princípios inatos à vida humana, defendidos pela fé cristã. Os direitos básicos da vida humana são proclamados e promovidos pela fé cristã. O cristianismo é uma religião defensora e promotora dos direitos da pessoa humana.

As reflexões conciliares sobre a dignidade da pessoa humana sancionam as meditações expostas, anteriormente, sobre a dimensão onto-axiológica da pessoa e sua superioridade em relação às demais criaturas; dimensão pessoal e relacional do ser humano; Deus como o fundamento de seu pessoal e interpessoal; a pessoa, em razão de seu valor inegociável, não se confunde com a sua natureza, não se dissolve num anonimato coletivista e nem pode ser usada como meio ou instrumento por instituições e organizações; a antropologia tem o seu desfecho na cristologia.

\section{A pessoa humana e a Declaração Universal dos Direitos Humanos}

Em 1945, com o fim da segunda guerra mundial e com a criação da ONU (Organização das Nações Unidas), os líderes mundiais decidiram elaborar um guia humanitário, com o intento de garantir os direitos e as liberdades de todas as pessoas, contra todas as atrocidades e barbáries, cuja extensão abrangesse todos os tempos e lugares. Neste contexto, foi a proclamada, no dia 10 de dezembro de 1948, em Paris, na terceira sessão da Assembleia Geral da ONU, a Declaração Universal dos Direitos Humanos (DUDH).

No preâmbulo da DUDH, o documento reconhece, que a dignidade humana, inerente a toda pessoa, é o fundamento da liberdade, da justiça e da paz no mundo. A dignidade, o valor e a igualdade de direitos são bens humanitários que dizem 
respeito a todo ser humano. Estes bens são inerentes à constituição cada pessoa. A desconsideração, com os direitos e as liberdades das pessoas, resultou em ações bárbaras, nos campos social (guerras), político (regimes totalitários, comunistas) e outros.

Sintetizando os principais artigos da DUDH, pode-se afirmar que todas as pessoas, sem distinção de qualquer espécie (raça, cor, sexo, língua, religião, nacionalidade, opção política, condição financeira e outras) nascem livres e iguais em dignidade e direitos (I-II). Toda pessoa tem direito à vida, à liberdade, à segurança pessoal (III), à propriedade (XVII), a um trabalho, à livre escolha de um emprego, a uma condição justa e favorável de trabalho, à proteção contra o desemprego, à igual remuneração por igual trabalho (XXIII), a repouso e a lazer (XXIV), à educação (XXVI), a um padrão de vida capaz de assegurar para si e para a sua família saúde e bem-estar (XXV), à liberdade de pensamento, consciência e religião (XVIII), à liberdade de locomoção, à emigração interna e externa, à residência (XIII), à liberdade de opinião e expressão (XIX), à reunião e associação (XX), à participação política e ao direito de participar da livre eleição do sistema político do povo a que pertence $(\mathrm{XXI})$, à nacionalidade $(\mathrm{XV})$, ao reconhecimento igualitário perante a lei (VI). Todas as pessoas são iguais perante a lei e têm direito, sem qualquer distinção, a igual proteção da lei (VII). Nenhuma pessoa pode ser submetida à escravidão ou à servidão (IV), à tortura, a um tratamento desumano ou degradante (V) e nem detida, exilada ou presa de forma arbitrária (IX). Toda pessoa maior de idade tem o direito de contrair um matrimônio e formar uma família (XVI).

Segundo J. Maritain (1967, p. 74), todos os direitos da pessoa humana estão "radicados na vocação da pessoa, agente espiritual e livre, às ordens dos valores absolutos e com um destino superior ao tempo". Os direitos da pessoa encontram justificativa no fundamento transcendente e no fim absoluto para o qual a pessoa está ordenada. Os direitos humanos consideram o ser humano em sua "condição humana e não por concessão de nenhuma autoridade" (LORDA, 2009, p. 186). 
Tratam-se de direitos naturais, que pertencem à natureza humana, por sua dignidade e valor. Não são direitos externos ou agregados à pessoa os quais lhe seriam conferidos por instituições sociais, políticas ou de outra ordem. Não se tratam de afirmações abstratas ou idealistas, mas que se referem à vida concreta de cada pessoa em sua dimensão pessoal, social, política, cultural, religiosa etc.

\begin{abstract}
A pessoa humana tem direitos, por isto mesmo que é uma pessoa, um todo senhor de si próprio de seus atos, e que por consequência, não é somente um meio, mas um fim, um fim que deve ser tratado como tal. A dignidade da pessoa humana - seria uma expressão vã se não significasse que, segundo a lei natural, a pessoa humana tem direito de ser respeitada e é sujeito de direito, possui direitos. Há coisas que pertencem de direito ao homem, simplesmente porque homem (MARITAIN, 1967, p. 62).
\end{abstract}

Pelo simples fato de ser uma pessoa, e não um fragmento material inanimado, é que o ser humano tem direitos. A declaração dos direitos humanos é uma explicitação, mais moral do que jurídica, daquilo que a priori é constituinte da pessoa humana. Eles não são uma conquista pessoal e nem um reconhecimento da sociedade, em razão de uma hipotética evolução moral da pessoa, mas a objetivação daquilo que está naturalmente implícito em cada pessoa possuidora de direitos naturais.

A ONU reconhece e explicita, porém não cria os direitos humanos. Os direitos humanos não emanam das declarações da ONU, mas são um reconhecimento de direitos pré-existentes. A DUDH é o reflexo de exigências objetivas e imprescindíveis de uma lei moral universal.

Propriamente falando, a questão dos direitos humanos é mais moral do que jurídica, já que são exigências prévias a todo ordenamento jurídico e tem um valor independentemente de seu reconhecimento legal. As declarações são somente expressão jurídica de umas exigências morais que nascem da dignidade humana (LORDA, 2009, p. 187).

A dimensão jurídica dos direitos humanos está na declaração legal, na institucionalização, daqueles direitos morais inerentes à pessoa. $\mathrm{O}$ reconhecimento 
da dignidade, da igualdade e da liberdade da pessoa são princípios basilares que antecedem o revestimento jurídico dos direitos humanos. A expressão "jurídica" está na progressiva tomada de consciência das relações entre a pessoa, a sociedade e o estado. Quando os direitos humanos são apresentados simplesmente em termos de legalidade, eles correm o risco de se tornarem débeis proposições separadas da dimensão ética e racional, que são o seu fundamento e finalidade.

A promoção dos direitos humanos é uma forma eficaz de eliminar as desigualdades em todos os níveis entre países e grupos sociais. Os direitos humanos são uma carta magna contra a opressão, a discriminação, a injustiça, a desumanidade e em defesa da igualdade, da dignidade e da liberdade da pessoa humana. O mérito da DUDH consiste em permitir, que diferentes culturas, expressões jurídicas e instituições possam convergir em torno de um núcleo fundamental de valores e de direitos referentes à pessoa humana, em suas várias dimensões.

Os países, que reconhecem os direitos fundamentais da pessoa humana, devem empenhar-se em criar condições básicas para que a vida seja vivida de forma digna e livre. Este empenho deve levar em consideração as condições particulares de cada país no que tange à sua cultura, vida social, política e econômica. Os países, que reconhecem os direitos humanos, devem esforçar-se por sancioná-los juridicamente (COMISSÃO TEOLÓGICA INTERNACIONAL, 2006, p. 277).

O que é genuinamente humano também é genuinamente cristão. O cristianismo é uma forma de humanismo crente. Muitos princípios formulados pela DUDH fazem parte da fé cristã, como por exemplo, o tratamento humano, digno, respeitoso e igualitário devotado a cada pessoa. A fé cristã não defende uma sobrevalorização de Deus e uma infravalorização da pessoa, mas prega que o mesmo respeito que se tem por Deus deve-se ter por cada pessoa, que é imagem de Deus. O cristianismo é uma declaração universal, em favor da dignidade e do valor 
absoluto de cada pessoa humana. Neste sentido, certamente, a fé cristã, assim como outras tradições religiosas e culturais, serviu de inspiração para a declaração dos direitos humanos. "A ideia da dignidade da pessoa humana e dos direitos do homem desenvolveu-se em boa parte sob o influxo da doutrina cristã em campo antropológico; encontrou confirmação nas declarações universais do nosso século" (COMISSÃO TEOLÓGICA INTERNACIONAL, 2006, p. 268).

O Papa Bento XVI, por ocasião da celebração dos 60 anos da DUDH, discursou na Assembleia da ONU, em Nova Iorque, no dia 18 de abril de 2008, recordando os fundamentos e as motivações da declaração: "O documento foi o resultado de uma convergência de tradições religiosas e culturais, todas motivadas pelo comum desejo de colocar a pessoa humana no centro das instituições, leis e intervenções da sociedade, e de considerar a pessoa humana essencial para o mundo da cultura, da religião e da ciência. Os direitos humanos estão cada vez mais presentes como linguagem comum e substrato ético das relações internacionais. Ao mesmo tempo, a universalidade, a indivisibilidade e a interdependência dos direitos humanos servem de garantia para salvaguardar a dignidade humana. Contudo, é evidente que os direitos reconhecidos e traçados na Declaração se aplicam a todos em virtude da comum origem da pessoa, a qual permanece o ponto de referência mais alto do desígnio criador de Deus para o mundo e para a história. Tais direitos estão baseados na lei natural inscrita no coração do homem e presente nas diversas culturas e civilizações"2

\section{Meditações conclusivas}

Depois de fazer este percurso filosófico-teológico pelo conceito de "pessoa" é possível perceber que a pessoa humana é uma magnitude substancial munida de uma dimensão relacional interna e um ser em relação, constituído por uma substancialidade. A pessoa humana é um todo relacional. Trata-se de um conjunto

\footnotetext{
${ }^{2}$ Disponível em www.vatican.va/holy_father/benedict_xvi/speeches/2008/april/documents (acessado dia 21 de novembro de 2013).
} 
de relações consigo mesma, com os outros, com Deus e com a criação. Como substancialidade, a pessoa é um ser que subsiste em si e se possui. É um ser que tem fim em si mesmo. Esta dimensão relacional-substancial é inerente à pessoa humana e não conferida por um agente externo.

Uma meditação sobre a pessoa humana evoca as noções de liberdade e de sociabilidade. Dizer pessoa é afirmar um ser livre e social. A liberdade e a sociabilidade pertencem à dimensão interna da pessoa. Não é o estado, a sociedade ou a religião que conferem liberdade à pessoa, mas ela já o é por si mesma e por sua natureza. A liberdade pessoal significa a "autodisposição do sujeito em direção à definitividade" (RAHNER, 2007, p. 203). A sociabilidade refere-se à sua condição relacional. A sociedade se forma em razão da vocação social da pessoa. O ostracismo e o isolamento estão na contramão da dimensão social da pessoa.

A pessoa humana tem um primado onto-axiológico sobre os demais seres criados, no sentido de que é e vale mais do que qualquer outra criatura. Esta visão não patrocina um antropocentrismo religioso, mas reconhece o apogeu criatural do ser humano em razão de sua condição de imagem de Deus. No âmbito da criação, todas as criaturas têm a mesma dignidade criacional, porque todas receberam sua existência como um dom da parte de Deus. Por isso, toda criatura tem o mesmo direito de cidadania na criação. No entanto, o ser humano, como síntese da criação e por sua condição de imago Dei (Gn 1,26), é o administrador do criado. A condição de imago Dei não permite ao ser humano ter uma relação despótica ou piramidal com as outras criaturas. O ser humano é zelador e cuidador e não dominador do criado. Seu primado onto-axiológico não lhe permite ter uma relação ditatorial com as demais criaturas. Se o ser humano é e vale mais, logo ele deve ser mais e cuidar mais das outras criaturas.

Há um desnível ontológico entre o ser de Deus e o ser pessoa humana. O ser de Deus "é" mais, no entanto, esta dessemelhança ontológica não pode ser acompanhada de uma sobrevalorização de Deus e uma infravalorização da pessoa. 
Se o ser humano é imagem de Deus, no sentido de ser o reflexo e o representante de Deus na criação, logo o mesmo respeito devotado a Deus, também deve ser prestado àquele que é a sua imagem, a pessoa. Uma reta compreensão da fé cristã, não concebe Deus como uma ameaça à soberania, à liberdade e à autonomia da pessoa. Para a antropologia cristã, o ser humano não é um ser subserviente e escravizado por Deus. A afirmação de Deus não consiste na negação do ser humano. Dizer Deus é afirmar o ser humano e vice-versa. O ser humano merece o mesmo respeito, reconhecimento e veneração prestados a Deus. O ser humano deve ser tratado como Deus, porque este mesmo Deus desejou, livremente, se fazer ser humano, em Jesus Cristo. O ser humano e Deus estão abraçados em Cristo. Ele é o ponto de encontro entre Deus e o ser humano.

O cristianismo, na medida em que se ocupa da defesa dos direitos, da dignidade, do valor e da igualdade de todas as pessoas, pode ser visto como um humanismo religioso. O que é genuinamente humano é genuinamente cristão. Neste sentido, cristianizar é humanizar. A pessoa está no centro gravitacional das preocupações da fé cristã. Evangelizar é promover humanamente a pessoa.

Enfim, a pessoa está relacionada com as verdades centrais e fundantes da fé cristã: encarnação e ressurreição. Na encarnação, Deus se torna corpo, mundo e assume um rosto antropológico. A pessoa humana é assumida no projeto de Deus. A encarnação é a humanização de Deus e a divinização do ser humano, como já afirmava a patrística. Deus não tangencia a carne humana ou assume uma carne idealizada, mas adentra e se apropria da carne de todo ser humano e do ser humano todo. Na encarnação, Deus se vincula a todo ser humano para ressuscitar todo ser humano. A relação de Deus com o ser humano não é concluída com a morte, mas continua num outro plano da existência. Na ressurreição, o corpo assumido é glorificado. Deus se mistura no barro da existência humana para que esta possa participar de sua glorificação. 


\section{REFERÊNCIAS}

AGOSTINHO. A Trindade. São Paulo: Paulus, 1995.

ALFARO, J. De la cuestión del hombre a la cuestión de Dios. 4. ed. Salamanca: Sígueme, 2002.

BOASSO, F. El rosto descubierto del misterio del hombre. Buenos Aires: Guadalupe, 1989.

BOÉCIO. Liber de Persona et Duabus Naturis. cap. III (Patrologia Latina 64, 1343 D).

BUBER, M. ¿Qué es el hombre?. Madrid: F.C.E. España, 1986.

BUBER, M. Eu e Tu. São Paulo: Centauro, 2001.

CLÉMENT, C. Questions sur l'homme. Paris: Stock, 1972.

COMISSÃO TEOLÓGICA INTERNACIONAL. Dignità e diritti della persona umana. In: ID. Documenti (1969-2004). Bologna: Studio Domenicano, 2006. p. 255-278.

DE LUBAC, H. El drama del humanismo ateo. 3. ed. Madrid: Encuentro, 2008. DESCARTES, R. Meditações. São Paulo: Nova Cultural, 1999.

DOCUMENTOS DO CONCÍLIO ECUMÊNICO VATICANO II (1962-11965). 4.ed. São Paulo: Paulus, 2007.

FEUERBACH, L. A essência do cristianismo. 2. ed. Campinas: Papirus, 1997.

FLICK, M.; Z. ALSZEGHY, Z. L’uomo nella teologia. Modena: Paoline, 1971.

GIORDANI, M.C. Iniciação ao existencialismo. Vozes: Petrópolis, 1997.

GUARDINI, R. O mundo e a pessoa. São Paulo: Livraria Duas Cidades, 1963.

HEGEL, G.W.F. El concepto de religión. México: Fondo de Cultura Económica, 1981.

HUME, D. Investigação acerca do entendimento humano. São Paulo: Nova Cultural, 1999.

HUSSERL, E. Ideas. Madrid: Fondo de Cultura Económica, 1993.

INVITTO, G. "Deus não existe": A indemonstrabilidade de uma certeza. In: PENZO, G;

GIBELLINI, R. Deus na filosofia do século XX. São Paulo: Loyola, 1998. p. 409-420.

JOÃO DUNS ESCOTO. Dios uno y trino. Madrid: BAC, 1960.

LADARIA, L.F. Introdução à antropologia teológica. São Paulo: Loyola, 1998. 
LADARIA, L.F. O Deus vivo e verdadeiro. São Paulo: Loyola, 2005.

LOCKE, J. Ensaio acerca do entendimento humano. São Paulo: Nova Cultural, 1999.

LORDA, J.L. Antropología Teológica. Pamplona: Universidade de Navarra, 2009.

MARÍAS, J. Antropologia Metafísica. São Paulo: Duas Cidades, 1971.

MARITAIN, J. Os direitos do homem. 3 ed. Rio de Janeiro: Livraria José Olympio, 1967.

MARX, K.; ENGELS, F. El manifiesto comunista: Once tesis sobre Feuerbach. Madrid: Alhambra, 1986.

MCPARTlan, P. Pessoa. In: Dicionário Crítico de Teologia. São Paulo: LoyolaPaulinas, 2004. p. 1393-1399.

MOLTMANN, J. Uomo. 2. ed. Brescia: Queriniana, 1991.

MOUNIER, E. O personalismo. São Paulo: Livraria Duas Cidades, 1964.

MÜlleR, M.; HALDER, A. Persona. In: Sacramentum Mundi. Barcelona: Herder, 1974. p. 444-456.

RAHNER, K. Teología de la liberdad. In: ID. Escritos de Teología. 2. ed. Madrid: Cristiandad, V.6, 2007.p. 195-213.

RAHNER, K. O conceito de mistério na teologia católica. In: ID. O dogma repensado. São Paulo: Paulinas, 1970. p. 153-216.

RAHNER, K. Reflexões fundamentais sobre a antropologia e a protologia no conjunto da teologia. In: FEINER, J; LOEHRER, M. Mysterium Salutis. Petrópolis: Vozes, 1972. v. II/2, p. 6-19.

RAHNER, K. Dignidad y liberdad del hombre. In: ID. Escritos de Teología. 2 ed. Madrid: Cristiandad, v. 2,2002. p. 231-257.

RAHNER, K. Curso fundamental da fé. 2 ed. São Paulo: Paulus, 1989.

PANNENBERG, W. Teología y Reino de Dios. Salamanca: Sígueme, 1974.

RATZINGER, J. Introdução ao Cristianismo. São Paulo: Loyola, 2005.

RATZINGER, J. Dogma e anúncio. São Paulo: Loyola, 2007.

PERSONA. In: RAHNER, K.; VORGRIMLER. H.Dizionario di Teologia. Roma-Brescia: Herder-Morcelliana, 1968. p. 500-505.

PESSOA. In: MORA, J.F. Dicionário de Filosofía. São Paulo: Loyola, 2001. v. 3, p. 2262-2265. 
RICARDO DE SÃO VITOR, De Trinitate, livro IV, cap. 22 (Patrologia Latina 196, 945).

ROVIRA Belloso, J.M. Pessoas divinas. In: Dicionário Teológico O Deus Cristão. São Paulo: Paulus, 1998. p. 699-708.

RUBIO, A.G. Unidade na pluralidade. 3 ed., São Paulo: Paulus, 2001.

RUIZ DE LA PEÑA, J.L. Imagen de Dios. Santander: Sal Terrae, 1988.

RUIZ DE LA PEÑA, J.L. Crisis y apología de la fe. Santander: Sal Terrae, 1995.

SAYÉS, J.A. Teología de la creación. Madrid: Palabra, 2002.

SARTRE, J.P. O ser e o nada. 19. ed. Petrópolis: Vozes, 2011.

SCHEFFCZYK, L. O homem moderno e a imagem bíblica do homem. São Paulo: Paulinas, 1976.

SCHELER, M. Ética: nuevo ensayo de fundamentación de un personalismo ético. Buenos Aires: Revista de Occidente Argentina, 1948. v. 1.

SCHELER, M. Ética: nuevo ensayo de fundamentación de un personalismo ético. Buenos Aires: Revista de Occidente Argentina, 1948. v. 2.

SCHÜTZ, C.; SARACH, R. O homem como pessoa. In: FEINER, J.; LOEHRER, M. Mysterium Salutis. Petrópolis: Vozes, 1973. v. II/3, p. 73-89.

SCOLA, A.; MARENGO, G.; PRADES LÓPEZ, J. La persona umana: antropologia teologica. Milano: Jaca Book, 2000.

SIERRA, A.M. Antropología teológica fundamental. Madrid: BAC, 2002.

TOCQUER, R. Que é o homem? Ensaio de antropologia cristã. São Paulo: Flamboyant, 1960.

TOMÁS DE AQUINO. Suma Teológica. São Paulo: Loyola, 2001.

VALVERDE, C. Antropología filosófica. Valencia: Edicep, 1995.

VILLA, M.M. Pessoa. In: ID. Dicionário de Pensamento Contemporâneo. São Paulo: Paulus, 2000. p. 594-601.

ZUBIRI, X. El hombre y Dios. Madrid: Alianza, 1984.

ZUBIRI, X. Sobre el hombre.Madrid: Alianza, 1986.

WERBICK, J. Pessoa. In: Dicionário de conceitos fundamentais de teologia. São Paulo: Paulus, 1993. p. 678-683. 